\title{
Trace-element geochemistry of diamond-hosted olivine inclusions from the Akwatia Mine, West African Craton: implications for diamond paragenesis and geothermobarometry
}

\author{
J. C. M. De Hoog ${ }^{1}$ T. Stachel ${ }^{2}$ J. W. Harris ${ }^{3}$
}

Received: 8 May 2019 / Accepted: 16 October 2019 / Published online: 14 November 2019

(C) The Author(s) 2019

\begin{abstract}
Trace-element concentrations in olivine and coexisting garnets included in diamonds from the Akwatia Mine (Ghana, West African Craton) were measured to show that olivine can provide similar information about equilibration temperature, diamond paragenesis and mantle processes as garnet. Trace-element systematics can be used to distinguish harzburgitic olivines from lherzolite ones: if $\mathrm{Ca} / \mathrm{Al}$ ratios of olivine are below the mantle lherzolite trend $(\mathrm{Ca} / \mathrm{Al}<2.2)$, they are derived from a harzburgitic mantle source, and syngenetic garnets are without exception subcalcic G10 garnets. For harzburgitic olivines that cannot be identified this way, $\mathrm{Na}$ and $\mathrm{Ca}$ contents can be used: olivine inclusions with $<60 \mu \mathrm{g} / \mathrm{g} \mathrm{Na}$ and $\mathrm{Na} / \mathrm{Al}<0.7$ are all harzburgitic, whereas those with $>300 \mu \mathrm{g} / \mathrm{g}$ Ca or $>60 \mu \mathrm{g} / \mathrm{g} \mathrm{Na}$ are lherzolitic. Conventional geothermobarometry indicates that Akwatia diamonds formed and resided close to a $39 \mathrm{~mW} / \mathrm{m}^{2}$ conductive geotherm. A similar value can be derived from $\mathrm{Al}$ in olivine geothermometry, with $T_{\mathrm{Al}-\mathrm{ol}}$ ranging from 1020 to $1325^{\circ} \mathrm{C}$. Ni in garnet temperatures is on average somewhat higher $\left(T_{\mathrm{Ni} \text {-grt }}=1115-1335^{\circ} \mathrm{C}\right)$ and the correlation between the two thermometers is weak, which may be not only due to the large uncertainties in the calibrations, but also due to disequilibrium between inclusions from the same diamond. Calcium in olivine should not be used as a geothermobarometer for harzburgitic olivines, and often gives unrealistic $P-T$ estimates for lherzolitic olivine as well. Diamond-hosted olivine inclusions indicate growth in an extremely depleted (low $\mathrm{Ti}, \mathrm{Ca}, \mathrm{Na}$, high $\mathrm{Cr} \#$ ) environment with no residual clinopyroxene. They are distinct from olivines from mantle xenoliths which show higher, more variable Ti contents and lower $\mathrm{Cr} \#$. Hence, most olivine inclusions in Akwatia diamonds escaped the refertilisation processes that have affected most mantle xenoliths. Lherzolitic inclusions are probably the result of refertilisation after undergoing high-degree melting first. Trivalent cations appear to behave differently in harzburgitic diamond-hosted olivine inclusions than lherzolitic inclusions and olivine from mantle xenoliths. Some divalent chromium is predicted to be present in most olivine inclusions, which may explain high concentrations up to $0.16 \mathrm{wt} \% \mathrm{Cr}_{2} \mathrm{O}_{3}$ observed in some diamond inclusions. Strong heterogeneity of $\mathrm{Cr}, \mathrm{V}$ and $\mathrm{Al}$ in several inclusions may also result in apparent high $\mathrm{Cr}$ contents, and is probably due to late-stage processes during exhumation. However, in general, diamond-hosted olivine inclusions have lower $\mathrm{Cr}$ and $\mathrm{V}$ than expected compared to mantle xenoliths. Reduced $\mathrm{Na}$ activity in depleted harzburgites limits the uptake of $\mathrm{Cr}, \mathrm{V}$ and $\mathrm{Sc}$ via $\mathrm{Na}-\mathrm{M}^{3+}$ exchange. In contrast, $\mathrm{Al}$ partitioning in harzburgites is not significantly reduced compared to lherzolites, presumably due to uptake of $\mathrm{Al}$ in olivine by $\mathrm{Al}-\mathrm{Al}$ exchange.
\end{abstract}

Keywords Diamond inclusions · Olivine $\cdot$ Geothermobarometry $\cdot$ Mantle petrology

Communicated by Daniela Rubatto.

Electronic supplementary material The online version of this article (https://doi.org/10.1007/s00410-019-1634-y) contains supplementary material, which is available to authorized users.

J. C. M. De Hoog

ceesjan.dehoog@ed.ac.uk

1 School of GeoSciences, The University of Edinburgh, Grant Institute, James Hutton Road, Edinburgh EH9 3FE, UK
2 Department of Earth and Atmospheric Sciences, University of Alberta, Edmonton, AB T6G 2E3, Canada

3 School of Geographical and Earth Sciences, University of Glasgow, Gregory Building, Glasgow G12 8QQ, UK 


\section{Introduction}

The subcontinental lithospheric mantle (SCLM) beneath cratons has been studied extensively as it is a key source of information about the geological and tectonic history of the early Earth. As the main source of diamonds, it is also an important economic reservoir. Olivine is a common inclusion in such diamonds (Sobolev et al. 2008; Stachel and Harris 2008), as well as the most common mineral in Earth's upper mantle, and may as such be an important tool in elucidating mantle and diamond formation processes. However, due to its low trace element contents and the lack of an empirical framework to interpret olivine data, its full potential has not been explored (De Hoog et al. 2010; Foley et al. 2013) and it is rarely used as an indicator mineral for diamond prospecting (e.g., Shchukina and Shchukin 2018).

Inclusions in diamonds are of particular interest because diamonds are robust containers shielding inclusions from secular processes in the Earth's mantle, and thus provide a window into early mantle processes that have been overprinted in mantle xenolith suites (Stachel and Harris 2008). For example, it has been noted that garnet inclusions in diamonds contain a much larger fraction of Ca-depleted garnets than mantle xenoliths from the same locality, and that olivine inclusions in diamonds can have much higher $\mathrm{Cr}_{2} \mathrm{O}_{3}$ contents (up to $0.5 \mathrm{wt} \%$ ) than commonly recorded in olivine from mantle xenoliths (up to $0.1 \mathrm{wt} \%$; De Hoog et al. 2010; Hervig et al. 1980b; Sobolev et al. 2009; Stachel and Harris 2008).

Diamond formation is associated with garnet-bearing sections of the SCLM in which harzburgites predominate over lherzolites (Gurney et al. 1993). Harzburgitic assemblages with strongly Ca-depleted garnets (G10 garnets; Dawson and Stephens 1975; Grütter et al. 2004) are of particular interest, as these are indicators for diamondiferous kimberlites (Gurney 1984; Gurney et al. 1993). Peridotitic inclusions in diamonds have been subdivided into lherzolitic and harzburgitic paragenesis (i.e., mantle source lithologies) based on the presence or absence of cpx and the Ca-saturation of garnet (Sobolev et al. 1973; Stachel and Harris 2008). However, many diamonds contain olivine inclusions only and currently no criteria exist to date to determine their paragenesis. Attempts to use olivine in diamond exploration have mainly focussed on identifying olivine from kimberlite, i.e., as a kimberlite indicator mineral (e.g., Matveev and Stachel 2007; Shchukina and Shchukin 2018), but this gives little indication about diamond potential. An olivine classification scheme that would identify harzburgitic olivines would increase its potential for use as a diamond indicator mineral.

Inclusions in diamonds may also provide constraints on the pressure-temperature conditions of diamond formation. These conditions can be estimated based on the chemical composition of co-existing minerals within the diamond, assuming that they were trapped simultaneously (i.e., syngenetic) or at least under similar chemical and $P-T$ conditions. The requirement of equilibrium between co-existing minerals does not apply to single-element thermometers, such as single cpx thermobarometry (Nimis and Taylor 2000), Al in olivine thermometry (De Hoog et al. 2010) or Ni in garnet (Canil 1996; Ryan et al. 1996), as these are assumed to be in equilibrium with a relatively constant source. However, few, if any, studies have evaluated the validity of olivine-based single-element thermometers for diamond-hosted inclusions.

A further source of uncertainty in interpreting trace element data is the influence of the chemical environment on trace element partitioning. For example, different exchange mechanisms appear to operate for $\mathrm{Cr}$ and $\mathrm{Al}$ in olivine in spinel vs. garnet peridotites (De Hoog et al. 2010; Witt-Eickschen and O'Neill 2005). As Na may act to charge balance trivalent cations (De Hoog et al. 2010; Hervig et al. 1986), the absence of clinopyroxene in harzburgitic lithologies prevalent in the mantle source of diamonds may affect trace element distributions and its use in tracing mantle processes and geothermometry.

This study aims to evaluate: diamond paragenesis based on the trace element compositions of olivine inclusions, the validity of trace element geothermometry, and the use of olivine to study mantle processes. The diamond suite used is from Akwatia, Ghana, in which olivine is a common inclusion and frequently co-exists with garnet (Stachel and Harris 1997a, b). It is, therefore, an ideal suite for the purpose of this study.

\section{Previous work on trace elements in mantle olivine}

Due to the low concentrations in olivine of many elements that are major or minor elements in co-existing minerals, trace element data for olivine are relatively scarce. Routine analytical settings for EMPA analysis often result in inadequate precision and detection limits for elements such as $\mathrm{Na}, \mathrm{Al}, \mathrm{Ca}, \mathrm{Cr}$ and $\mathrm{Ti}$ in olivine, especially in mantle peridotites, where concentrations of these elements are particularly low. Therefore, analysis of these elements needs to be done by LA-ICP-MS (De Hoog et al. 2010; Foley et al. 2013) or SIMS (Hervig et al. 1986; Steele et al. 1981), or using a dedicated trace element routine by EPMA (Batanova et al. 2015). Alternatively, bulk analysis may yield excellent results, but extreme care needs to be taken to pick clean olivine grains clear of fractures and inclusions (Stead et al. 2017). Due to their even lower concentrations, most trace elements other than the above-mentioned are only achievable 
by LA-ICP-MS (Stead et al. 2017; Witt-Eickschen and O'Neill 2005), but this is a destructive technique usually not suitable for precious samples such as diamond-hosted inclusions.

Despite these analytical challenges, work on trace elements in olivine goes back to the early 1980s. A small set of trace elements in olivine from spinel peridotites was presented by Stosch (1981), who used temperature-dependent partitioning of $\mathrm{Sc}$ and $\mathrm{Cr}$ between olivine and cpx to derive single-element geothermometers. A set of pioneering studies by Hervig and collaborators (Hervig and Smith 1982; Hervig et al. 1980a, b, 1986; Steele et al. 1981) presented trace-element data of olivine and co-existing minerals from a wide range of mafic to ultramafic rocks including kimberlite-derived lherzolites and harzburgites, as well as olivine inclusion in diamonds. They noticed temperature-dependent partitioning of elements such as $\mathrm{Cr}, \mathrm{Al}$ and $\mathrm{Na}$, and suggested the use of $\mathrm{TiO}_{2}$ to trace mantle metasomatism. A large excess of $\mathrm{Cr}$ was reported in some olivine inclusions in diamonds and a different crystallisation environment was inferred (Hervig et al. 1980b). Temperature dependence of trace element partitioning in spinel peridotites was studied in more detail by Witt-Eickschen and O'Neill (2005), but no $\mathrm{Al}$ or $\mathrm{Na}$ was measured in their olivines.

Sobolev et al. $(2008,2009)$ presented a large dataset of minor element data from olivine inclusions in diamonds, which showed a large variation in elements such as $\mathrm{Ca}$ and $\mathrm{Cr}$, and distinct differences between diamond-hosted olivine inclusions and olivine from mantle xenoliths. De Hoog et al. (2010) presented a large database of olivine trace element data from mostly garnet-bearing lherzolitic mantle xenoliths from a variety of tectonic settings, which allowed them to calibrate several single-element geothermometers, of which the $\mathrm{Al}$ in olivine thermometer was the most promising, as well as identify geochemical parameters diagnostic for various mantle processes, such as melting and refertilisation. A review paper by Foley et al. (2013) expanded on the dataset by De Hoog et al. (2010) by including a wide suite of igneous rocks and showing olivine to be a sensitive tracer of melt metasomatism. Recent work has also provided data for supra-subduction zone xenoliths, an important reservoir (Ionov 2010; Pirard et al. 2013; Tollan et al. 2017) missing from previous compilations. The increase in interest of the behaviour of $\mathrm{H}$ in nominally anhydrous minerals has led to many studies about the interaction between trace element uptake in olivine with hydrogen (e.g., Berry et al. 2005, 2007; Tollan et al. 2018), showing that trace element partitioning can be strongly influenced by the chemical environment.

Despite all the work mentioned above, olivine data from garnet peridotites are still scarce and existing datasets are often incomplete. For instance, garnet peridotite data in Foley et al. (2006) and Glaser et al. (1999) lacked Al and Na

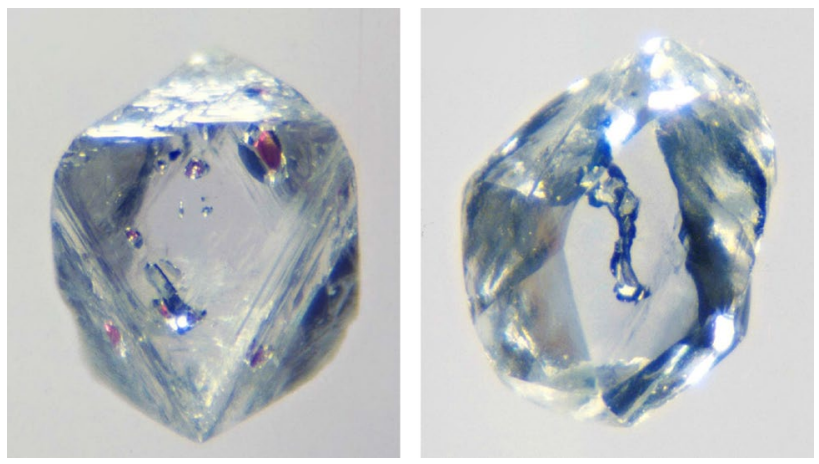

Fig. 1 Photographs of Akwatia diamonds containing silicate mineral inclusions. Left: diamond with red inclusions of pyrope garnet; right: diamond with pale-green to transparent olivine inclusions. Diamond size ca. $3 \mathrm{~mm}$

or $\mathrm{Ca}$, whereas the large available dataset of olivine inclusions in diamonds (Sobolev et al. 2009) lacks Na and other trace elements such as $\mathrm{V}$ and $\mathrm{Sc}$, whilst Ti is often near the detection limit of the EPMA technique. Due to incomplete datasets, trace element exchange mechanisms in olivine from garnet peridotite are still poorly constrained, and so are potential effects on empirically derived trace element geothermobarometers. This is particularly true for diamondhosted olivine inclusions.

\section{Samples}

The alluvial Birim diamond fields near Akwatia, Ghana, are located within Birimian (Early Proterozoic) metasedimentary rocks forming the south-eastern part of the West Africa Craton (Chirico et al. 2010; see also Electronic Supplement, Fig. S1). Akwatia diamonds show little evidence of transport and are associated with metamorphosed ultramafic rocks with a composition resembling komatiite or boninitetype volcanic rocks, similar to occurrences at Dachine in French Guyana and at Wawa in Ontario, Canada (Canales and Norman 2003). The eruption age of the diamonds is around $2.2 \mathrm{Ga}$ (Gurney et al. 2010). They contain abundant silicate inclusions of peridotitic (Fig. 1), the most abundant of which is olivine $(66 \%$ of inclusions are monomineralic olivine, another $15 \%$ occur in bimineralic and tri-mineralic assemblages; Stachel and Harris 1997b). The diamonds are dominantly derived from an initially strongly depleted but subsequently refertilised mantle source (Stachel and Harris 1997a).

This study presents new major and trace element data for 28 olivine inclusions from 25 Akwatia diamonds, as well as for garnets coexisting with 23 of the olivines. Of these inclusions, 5 are of lherzolitic paragenesis (co-existing with 
lherzolitic garnet or cpx), 19 are harzburgitic (co-existing with harzburgitic garnet) and 4 belong to the peridotitic suite but are of unknown paragenesis (no co-existing garnet or cpx).

Silicate inclusions were extracted by crushing the host diamond, embedded in epoxy and polished to a $1 / 4 \mu \mathrm{m}$ finish. Most inclusions were euhedral to subhedral in shape and mostly $100-500 \mu \mathrm{m}$ in size; typical examples are shown in Fig. 3. No spatial information about the inclusions was recorded, other than that none of the inclusions were touching.

\section{Analytical methods}

\section{Electron microprobe}

Major and minor elements were measured by electron probe Cameca SX-100 in the School of GeoSciences, University of Edinburgh. Major elements $\mathrm{Mg}, \mathrm{Si}$ and Fe were measured using a $10 \mathrm{nA}$ beam current at $15 \mathrm{kV}$ and a counting time of $60 \mathrm{~s}$ on both peak and background, whereas minor elements were measured using a higher beam current of $80 \mathrm{nA}$ and longer counting times of $240 \mathrm{~s}(\mathrm{Na}, \mathrm{Al}, \mathrm{Ca}, \mathrm{Cr})$ or $120 \mathrm{~s}(\mathrm{Mn}$, $\mathrm{Ni}$ ) on both peak and background. Calibration standards were forsterite $(\mathrm{Mg}, \mathrm{Si})$, fayalite $(\mathrm{Fe})$, wollastonite $(\mathrm{Ca}), \mathrm{Mg}$ spinel (Al), jadeite $(\mathrm{Na})$ and pure metals for the remaining elements (Cr, Ni, Mn). Accuracy and precision were monitored by repeat analysis of San Carlos olivine from USGS (USNM\# 111312/44; Jarosewich et al. 1980), in-house olivine standard DC0212 (see De Hoog et al. 2010, for preparation and details) and an in-house Cr-diopside standard, the latter mainly to monitor elements which are low in olivine $(\mathrm{Na}, \mathrm{Al}, \mathrm{Ca}, \mathrm{Cr})$. Four or five analyses were performed for each olivine to test their homogeneity.

\section{Ion microprobe-olivine trace elements}

Trace elements were measured by secondary ion mass spectrometry (SIMS) using the Cameca ims-4f at Edinburgh Ion Microprobe Facility. A $10 \mathrm{nA}^{16} \mathrm{O}^{-}$primary beam was focussed and impacted onto the samples at $14.5 \mathrm{kV}$; sputtered high-energy $(75 \pm 25 \mathrm{eV})$ positive secondary ions were collected at low mass resolution in six cycles of $5 \mathrm{~s}$ for each isotope, except ${ }^{47} \mathrm{Ti}$, which was measured for $15 \mathrm{~s} /$ cycle. Spot size was approximately $15 \times 20 \mu \mathrm{m}$. The following isotopes were measured (those in brackets were used for interference corrections, see details below): ${ }^{7} \mathrm{Li},{ }^{23} \mathrm{Na},{ }^{27} \mathrm{Al},{ }^{30} \mathrm{Si},{ }^{31} \mathrm{P},{ }^{39} \mathrm{~K},\left({ }^{40} \mathrm{Ca}\right),\left({ }^{41} \mathrm{~K}\right)$, ${ }^{43} \mathrm{Ca},\left({ }^{44} \mathrm{Ca}\right),{ }^{45} \mathrm{Sc},{ }^{47} \mathrm{Ti},\left({ }^{48} \mathrm{Ti}\right),\left({ }^{49} \mathrm{Ti}\right),{ }^{51} \mathrm{~V},{ }^{52} \mathrm{Cr},\left({ }^{53} \mathrm{Cr}\right)$, ${ }^{55} \mathrm{Mn},{ }^{59} \mathrm{Co},{ }^{62} \mathrm{Ni}$. Note that none of the $\mathrm{Mg}$ isotopes could be measured due to their high concentrations in olivine. Significant molecular isobaric interferences occur for several elements; most importantly $\mathrm{MgO}^{+}$(impacting mass 40-42), $\mathrm{SiO}^{+}$(impacting mass $44-46$ ), $\mathrm{MgMg}^{+}$(impacting mass 48-52) and $\mathrm{MgSi}^{+}$(impacting mass 52-56). The contribution of these interferences to the isotopes of interest was determined in the following order:

1. ${ }^{25} \mathrm{Mg}^{16} \mathrm{O}$ was measured at mass 41 and corrected for ${ }^{41} \mathrm{~K}$ (calculated from measured ${ }^{39} \mathrm{~K}$ based on their relative isotopic abundance), which allows calculation of ${ }^{24} \mathrm{Mg}^{16} \mathrm{O}$ contribution to ${ }^{40} \mathrm{Ca}$;

2. ${ }^{28} \mathrm{Si}^{16} \mathrm{O}$ was measured at mass 44 and corrected for ${ }^{44} \mathrm{Ca}$ (calculated from measured ${ }^{40} \mathrm{Ca}$ based on their relative isotopic abundance), which allows calculation of ${ }^{29} \mathrm{Si}^{16} \mathrm{O}$ contribution to ${ }^{45} \mathrm{Sc}$;

3. ${ }^{24} \mathrm{Mg}^{25} \mathrm{Mg}$ was measured at mass 49 and corrected for ${ }^{49} \mathrm{Ti}$ (calculated from measured ${ }^{47} \mathrm{Ti}$ based on their relative isotopic abundance, after correction of ${ }^{47} \mathrm{Ti}$ for ${ }^{29} \mathrm{Si}^{18} \mathrm{O}$ ), which allows calculation of ${ }^{25} \mathrm{Mg}^{26} \mathrm{Mg}$ contribution to ${ }^{51} \mathrm{~V}$ and ${ }^{26} \mathrm{Mg}^{26} \mathrm{Mg}$ contribution to ${ }^{52} \mathrm{Cr}$;

4. ${ }^{24} \mathrm{Mg}^{29} \mathrm{Si}+{ }^{25} \mathrm{Mg}^{28} \mathrm{Si}$ was measured at mass 53 and corrected for ${ }^{53} \mathrm{Cr}$ (calculated from measured ${ }^{52} \mathrm{Cr}$ based on their relative isotopic abundance), which allows calculation of ${ }^{25} \mathrm{Mg}^{30} \mathrm{Si}+{ }^{26} \mathrm{Mg}^{29} \mathrm{Si}$ contribution to ${ }^{55} \mathrm{Mn}$;

5. ${ }^{29} \mathrm{Si}^{30} \mathrm{Si}$ contribution to ${ }^{59} \mathrm{Co}$ was estimated using a $0.25 \%$ production rate of $\mathrm{SiSi}^{+}$from ${ }^{30} \mathrm{Si}$.

A small contribution of ${ }^{30} \mathrm{Si}^{16} \mathrm{O}_{2}{ }^{6}{ }^{62} \mathrm{Ni}$ was considered negligible due to the high $\mathrm{Ni}$ content of olivine. Average molecular production rates for $\mathrm{SiO}^{+} / \mathrm{Si}^{+}$and $\mathrm{MgSi}^{+} /$ $\mathrm{Si}^{+}$were $0.29 \%$ and $0.11 \%$, respectively. As a check for the validity of the $\mathrm{MgMg}$ correction on $\mathrm{V}$ and $\mathrm{Cr}$, it was measured on mass 48 as ${ }^{24} \mathrm{Mg}^{24} \mathrm{Mg}$ after correction ${ }^{48} \mathrm{Ca}$, ${ }^{48} \mathrm{Ti}$ and ${ }^{30} \mathrm{Si}^{18} \mathrm{O}$ and compared to $\mathrm{MgMg}$ measured on mass 49 (see step 3 above). The difference in $\mathrm{V}$ concentration calculated using $\mathrm{MgMg}$ measured on mass 48 or 49 , respectively, was generally $<3 \%$, showing that the analytical uncertainty added due to the interference corrections was small.

Although the measurements could have been made using high mass resolution of ca. $3000(M / \Delta M)$ to resolve molecular interferences, this would have been detrimental for the analysis of elements with low signals, in particular Sc, Ti and V.

Calibration was performed using in-house olivine standard DC0212 (LA-ICP-MS value, Table 3 in De Hoog et al. 2010), which was measured at least once every 4-8 analyses, using ${ }^{30} \mathrm{Si}$ as an internal standard. Standard deviation of 15 repeats on the standard was better than $5 \%$ for all elements except P (10\%) and Sc (20\%). To verify that SIMS data gave similar results as LA-ICP-MS data, olivine grain from selected Kaalvallei xenoliths from De 
Hoog et al. (2010) was re-analysed by SIMS. Agreement is overall excellent (Electronic Supplement, Fig. S2).

\section{Ion microprobe-garnet trace elements}

Selected trace elements in garnet were measured $(\mathrm{Ti}, \mathrm{Sc}, \mathrm{Ni}$, $\mathrm{V}, \mathrm{Co}$ ) by SIMS using the Cameca ims-1270 at EIMF, University of Edinburgh. $\mathrm{A}^{16} \mathrm{O}_{2}{ }^{-}$primary beam of $1-3 \mathrm{nA}$ was impacted onto the samples at $20 \mathrm{kV}$; sputtered positive ions were collected with no energy filtering in 15 cycles of $4 \mathrm{~s}$ for each isotope. Spot size was approximately $15 \times 10 \mu \mathrm{m}$. Measured isotopes were ${ }^{45} \mathrm{Sc},{ }^{49} \mathrm{Ti},{ }^{57} \mathrm{Fe},{ }^{50} \mathrm{Cr},{ }^{51} \mathrm{~V},{ }^{59} \mathrm{Co}$ and ${ }^{60} \mathrm{Ni}$. Potential molecular interferences on ${ }^{60} \mathrm{Ni}\left({ }^{30} \mathrm{Si}_{2},{ }^{28} \mathrm{SiO}_{2}\right.$, $\left.{ }^{44} \mathrm{CaO}\right),{ }^{45} \mathrm{Sc}\left({ }^{29} \mathrm{SiO}\right),{ }^{49} \mathrm{Ti}\left({ }^{24} \mathrm{Mg}^{25} \mathrm{Mg}\right),{ }^{51} \mathrm{~V}\left({ }^{25} \mathrm{Mg}{ }^{26} \mathrm{Mg}\right)$ and ${ }^{59} \mathrm{Co}\left({ }^{29} \mathrm{Si}^{30} \mathrm{Si}\right)$ were avoided using sufficiently high mass resolution $\left(M / \Delta M\right.$ ca. 4000 at $5 \%$ peak width). The ${ }^{50} \mathrm{Cr}$ signal was corrected for small contributions of ${ }^{50} \mathrm{Ti}$ and ${ }^{50} \mathrm{~V}$ isobars.

To use Ni in garnet as a thermometer, accuracy of the $\mathrm{Ni}$ content is essential. Therefore, in-house garnet standards that were prepared specifically for this application were used for calibration (Ivanic 2007). Nickel contents of the standards range from 41 to $140 \mu \mathrm{g} / \mathrm{g}$ and they have major element contents representative of those observed in mantlederived garnets. The same standards were used to calibrate $\mathrm{TiO}_{2}$ and $\mathrm{Cr}_{2} \mathrm{O}_{3}$. Working curves for $\mathrm{Ni}$, Ti and $\mathrm{Cr}$ show excellent correlations $\left(r^{2}=0.995-0.999\right.$; Electronic Supplement, Fig. S3). ${ }^{57} \mathrm{Fe}$ was used as internal standard using $\mathrm{FeO}$ contents measured by electron probe micro-analysis. Sc and Co were calibrated using two garnet standards (KP1, Binge Binge Point, and DDI, Dutsen Dushowo; Irving and Frey 1978). As V content is not known for any of the garnet standards in this study, it was measured by SIMS Cameca ims-4f at EIMF, University of Edinburgh. $\mathrm{A}^{16} \mathrm{O}^{-}$beam of $5 \mathrm{nA}$ was impacted onto the samples at $14.5 \mathrm{kV}$; sputtered positive ions were collected with $75 \mathrm{~V}$ energy offset in 10 cycles of $5 \mathrm{~s}$ for each isotope. Spot size was approximately $30 \times 25 \mu \mathrm{m}$. Measured isotopes were ${ }^{30} \mathrm{Si},{ }^{45} \mathrm{Sc},{ }^{47} \mathrm{Ti},{ }^{51} \mathrm{~V}$, ${ }^{52} \mathrm{Cr},{ }^{55} \mathrm{Mn}$ and ${ }^{60} \mathrm{Ni}$. Molecular interferences were negated using high mass resolution $(M / \Delta M$ ca. 2400 at $5 \%$ peak width). Basaltic glasses GSE1-G and GSD1-G were used for calibration (Jochum et al. 2005). Vanadium contents of KP1 and DDI garnet standards were determined as 41 and $134 \mu \mathrm{g} / \mathrm{g}$, respectively. Other elements agreed well with the data by Irving and Frey (1978).

\section{Mineral chemistry}

\section{Olivine}

\section{Major elements}

The olivine inclusions presented here are a subset of a larger suite of inclusions documented previously by Stachel and Harris (1997b). New major element data presented here (Table 1) agree well with previous data but show less scatter due to the improved analytical protocol (Fig. 2a, b). The olivines span a range of forsterite contents from 90.3 to 94.2\% (median $92.9 \%$ ); most show very little variation in Fo contents $(<0.1 \%)$ with maximum variations up to $0.3 \%$ in only few olivines. The lowest Fo values (90.3-92.9\%) are from lherzolitic inclusions, whereas harzburgitic olivines range from 92.6 to $94.3 \%$ (average $93.2 \%$ ). This is identical to the average mode of $93.2 \%$ for harzburgitic olivines from a global database of olivine inclusions in diamonds (Stachel and Harris 2008), and slightly higher than the average of 92.9\% from a large suite of diamond-hosted inclusions from Sobolev et al. (2009), which also included lherzolitic inclusions (Fig. 2b).

$\mathrm{MnO}$ contents range from 0.081 to $0.112 \mathrm{wt} \%$ (median $0.093 \mathrm{wt} \%$ ), apart from one high value of $0.15 \mathrm{wt} \%$, and show a well-defined negative correlation with Fo contents (Fig. 2a), which overlap with the diamond inclusions from Sobolev et al. (2009). NiO contents show a narrow range from 0.36 to $0.43 \mathrm{wt} \%$ (median $0.404 \mathrm{wt} \%$ ), which is higher than the global array of $\mathrm{NiO}$ contents in olivine inclusions in diamonds (0.36-0.38 wt\%; Stachel and Harris 2008; Sobolev et al. 2009). There is no correlation of $\mathrm{NiO}$ with Fo content, although the spread in $\mathrm{NiO}$ contents is larger for the olivines with the highest Fo contents (Fig. 2b). Lherzolitic olivines are near the high end of the range (0.40-0.43 wt\%), with the exception of anomalous lherzolitic olivine (G201-202), which also has low Fo and high $\mathrm{MnO}$.

\section{Trace elements}

Trace element contents of olivine inclusions are presented in Table 2. Lithium contents show a relatively wide range of concentrations from 0.6 to $2.8 \mu \mathrm{g} / \mathrm{g}$ (median $1.1 \mu \mathrm{g} / \mathrm{g}$; harzburgitic olivines are $<1.6 \mu \mathrm{g} / \mathrm{g}$ ), which spans the whole range of olivines from garnet-bearing peridotites from De Hoog et al. (2010). ${ }^{1}$ Lithium contents do not show any correlation with other elements. Sodium contents show a large

\footnotetext{
${ }^{1}$ Note that the olivine data from De Hoog et al. (2010) include data from garnet-free spinel peridotites and other rock types. When referring to these olivine data, we only included garnet-bearing peridotite xenoliths, unless otherwise stated.
} 


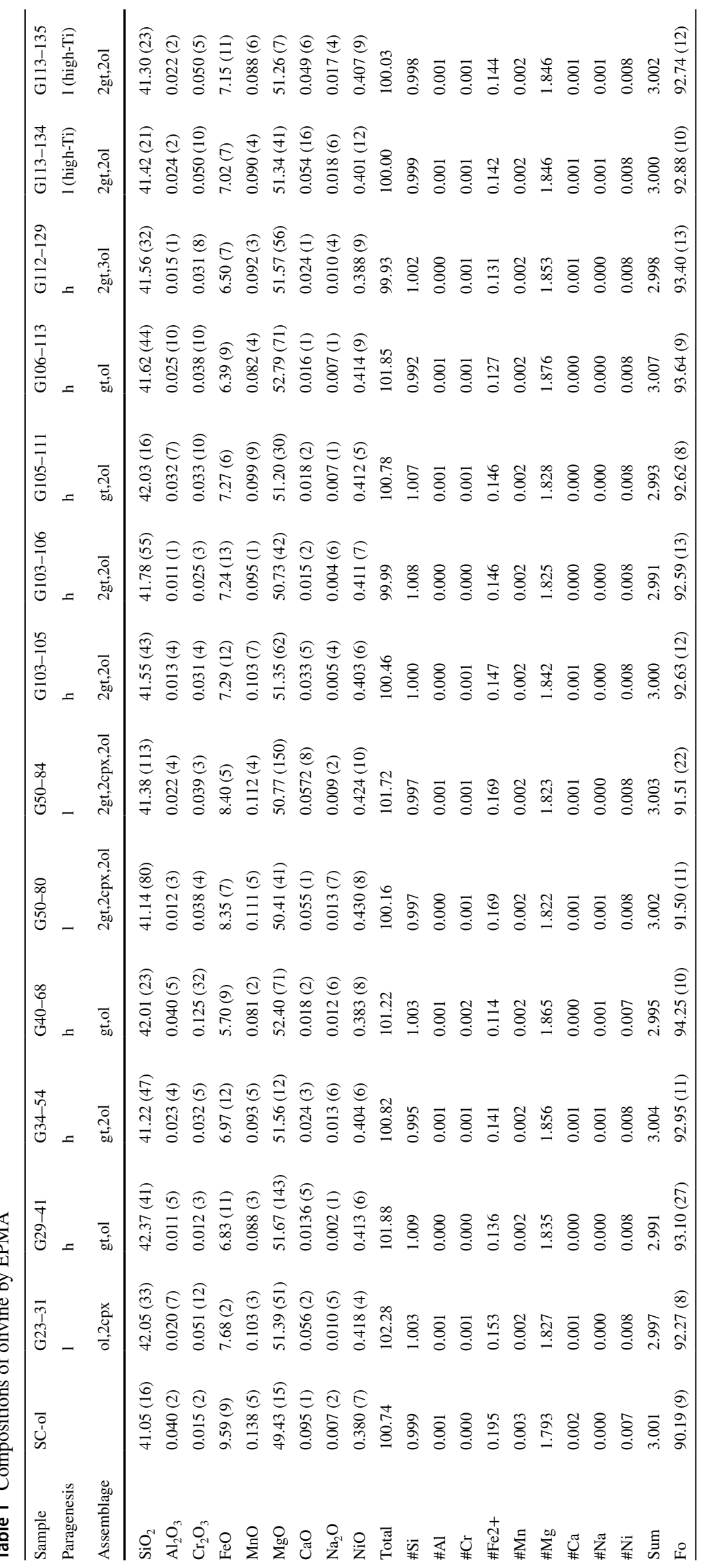




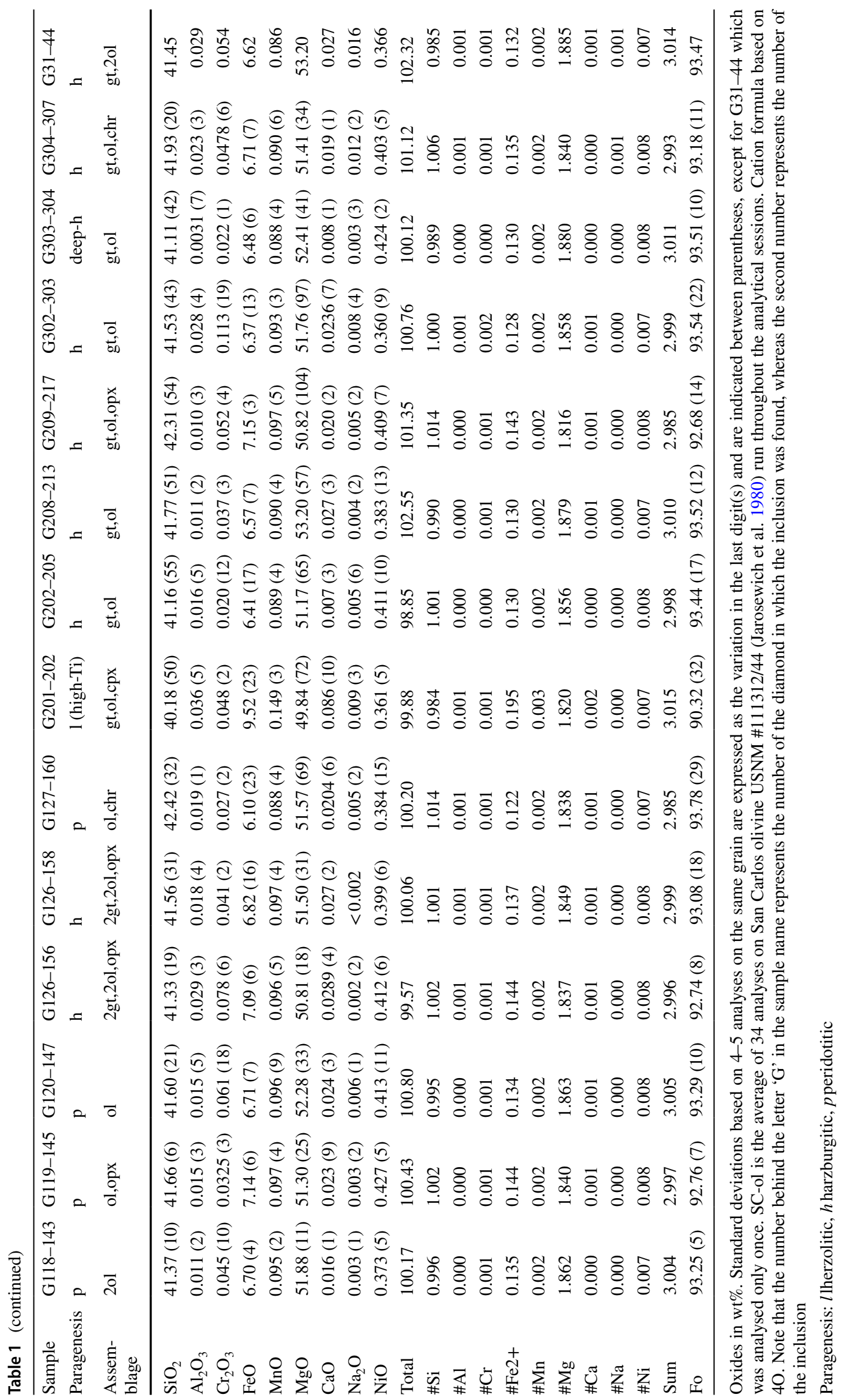




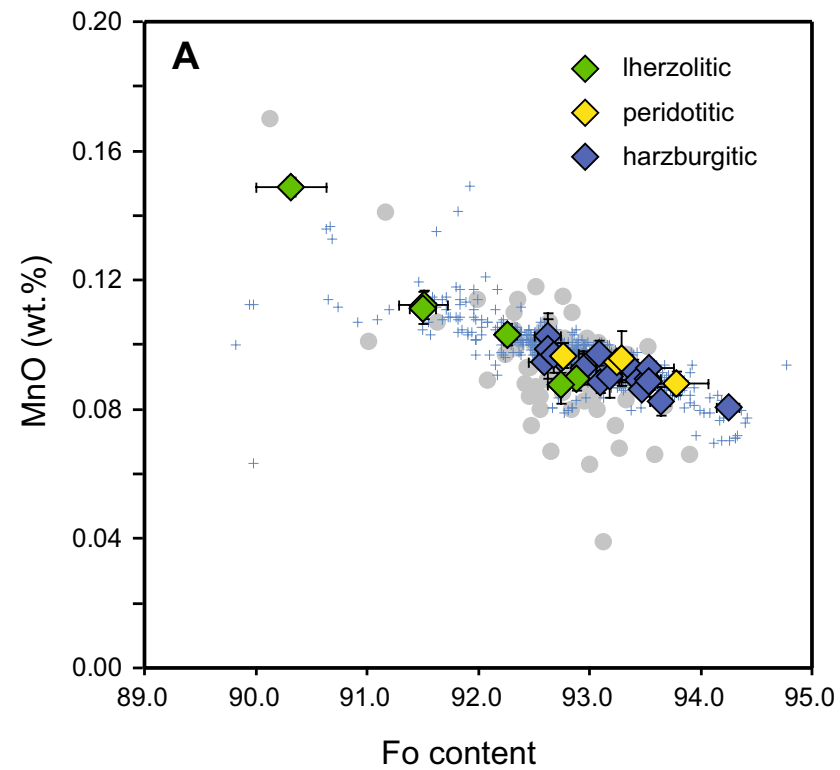

Fig. 2 a $\mathrm{MnO}$ and b $\mathrm{NiO}$ (wt\%) content of olivine inclusions in Akwatia diamonds vs. their forsterite (Fo\%) content. Error bars (1s) based on 4-5 repeat analyses on different locations on each grain. Grey dots are data from a larger suite of olivine inclusions in Akwa-

range $(1.3-115 \mu \mathrm{g} / \mathrm{g}$, median $28 \mu \mathrm{g} / \mathrm{g})$, but are low compared to lherzolitic olivines from garnet peridotite xenoliths (up to $300 \mu \mathrm{g} / \mathrm{g}$; De Hoog et al. 2010). Harzburgitic olivines have $<57 \mu \mathrm{g} / \mathrm{g} \mathrm{Na}$. Aluminium contents also show a wide range from 13 to $116 \mu \mathrm{g} / \mathrm{g}$ (median $64 \mu \mathrm{g} / \mathrm{g}$ ), with harzburgitic and lherzolitic olivine inclusions being similar and showing a comparable range to olivines from mantle xenoliths (De Hoog et al. 2010) and olivine inclusions in diamonds (Sobolev et al. 2009). Calcium concentrations fall between 34 and $565 \mu \mathrm{g} / \mathrm{g}$ (median $148 \mu \mathrm{g} / \mathrm{g}$ ); the highest values are from lherzolitic olivines. Scandium contents range from 0.5 to $2.6 \mu \mathrm{g} / \mathrm{g}$ (median $1.0 \mu \mathrm{g} / \mathrm{g}$ ) and show no correlation with other elements. Titanium contents are low $(<72 \mu \mathrm{g} / \mathrm{g}$, median $2.2 \mu \mathrm{g} / \mathrm{g})$ with values $>10 \mu \mathrm{g} / \mathrm{g}$ all from lherzolitic inclusions. The latter co-exist with Ti-rich garnets, but still have considerable less Ti than Ti-rich olivines in lherzolitic mantle xenoliths (up to $270 \mu \mathrm{g} / \mathrm{g}$; De Hoog et al. 2010). The highest Ti content in harzburgitic olivine is $9.6 \mu \mathrm{g} / \mathrm{g}$, but the median is only $1.0 \mu \mathrm{g} / \mathrm{g}$.

Vanadium contents vary from 0.7 to $10.3 \mu \mathrm{g} / \mathrm{g}$ (median $4.8 \mu \mathrm{g} / \mathrm{g}$ ), with one exception of $15 \mu \mathrm{g} / \mathrm{g}$. This is similar to the range observed in olivine from the xenoliths $(1-10 \mu \mathrm{g} / \mathrm{g}$; De Hoog et al. 2010). A weak positive correlation of $\mathrm{V}$ can be observed with $\mathrm{Cr}$, but this correlation is considerably less clear than in olivines from mantle xenolith (De Hoog et al. 2010). Chromium contents range from 120 to $1100 \mu \mathrm{g} / \mathrm{g}$ (median $350 \mu \mathrm{g} / \mathrm{g}$ ) with little difference between harzburgitic and lherzolitic inclusions. These values are considerably higher than those from mantle xenoliths, which range

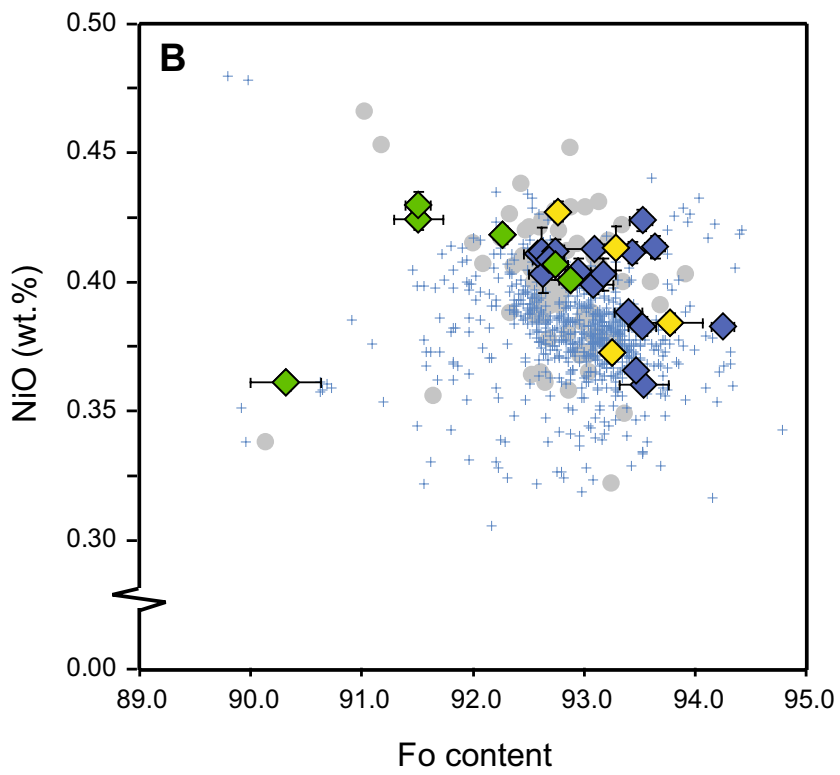

tia diamonds analysed at lower precision (Stachel and Harris 1997b), whereas small plus signs represent diamond-hosted olivine inclusions from Sobolev et al. (2009)

from 20 to $620 \mu \mathrm{g} / \mathrm{g}$ (De Hoog et al. 2010), as well as olivine inclusions in diamonds (Sobolev et al. 2009, which mostly range from 30 to $350 \mu \mathrm{g} / \mathrm{g}$, although a few higher values do occur. $\mathrm{Cr} \#(\# \mathrm{Cr} /[\# \mathrm{Cr}+\# \mathrm{Al}])$ range from 0.47 to 0.90 , with an average of 0.72 , which are also high compared to mantle xenoliths $(0.33-0.75$, average 0.64$)$ and diamond inclusions (average 0.54). Cobalt values range from 116 to $164 \mu \mathrm{g} / \mathrm{g}$ (median $133 \mu \mathrm{g} / \mathrm{g}$ ), with no difference between harzburgitic and lherzolitic inclusions, and are very similar to olivine inclusions in diamonds elsewhere $(100-181 \mu \mathrm{g} / \mathrm{g}$, average $129 \mu \mathrm{g} / \mathrm{g}$; Sobolev et al. 2009).

Duplicate ion microprobe analyses of olivine generally show excellent reproducibility for most elements (e.g., Mn, $\mathrm{Ni}, \mathrm{Co}, \mathrm{Ti}$ ) but occasionally large differences for $\mathrm{Cr}$ and $\mathrm{V}$, and, to a lesser extent, $\mathrm{Na}, \mathrm{Al}$ and $\mathrm{Ca}$. This variability was confirmed by high-resolution line scans across several olivines by EPMA (Fig. 3) as well as a Cr map of one of the grains (Electronic Supplement, Fig. S4). The patterns are mostly highly irregular for $\mathrm{Cr}$ but flat for $\mathrm{Mn}$, whereas $\mathrm{Ca}$ and $\mathrm{Al}$ correlate with $\mathrm{Cr}$ for some inclusions (G106-113, G112-129; Fig. 3) and are flat in others (G105-111; Fig. 3). The variability in $\mathrm{Cr}$ and $\mathrm{V}$ may be due to the presence of nano-inclusions of chromite, which have been reported in a olivine inclusion in diamond from Yakutia (Sobolev et al. 2008), but no such inclusions could be observed in Akwatia olivines even at very high magnification using BSE imaging. Hence, if such inclusions exist they must be smaller than $0.1 \mu \mathrm{m}$, in which case their presence cannot explain the large variability under the ion microprobe beam (which is 
Table 2 Trace-element concentrations of olivine inclusions by SIMS

\begin{tabular}{|c|c|c|c|c|c|c|c|c|c|c|c|c|}
\hline Sample & Par. & Fo & $\mathrm{Li}$ & $\mathrm{Na}$ & $\mathrm{Al}$ & $\mathrm{Ca}$ & Sc & $\mathrm{Ti}$ & V & $\mathrm{Cr}$ & $\mathrm{Mn}$ & Co \\
\hline G23-31 & 1 & 92.3 & 0.9 & 62 & 80 & 351 & 0.7 & 5.8 & 5.1 & 350 & 797 & 142 \\
\hline G29-41 & $\mathrm{h}$ & 93.1 & 1.1 & 3 & 38 & 84 & 0.7 & 0.2 & 2.5 & 130 & 697 & 133 \\
\hline G30-40 & $\mathrm{h}$ & 92.3 & 0.9 & 10 & 29 & 117 & 0.7 & 4.5 & 4.7 & 243 & 725 & 125 \\
\hline G32-46 & $\mathrm{h}$ & 92.6 & 1.3 & 11 & 77 & 215 & 1.1 & 2.7 & 3.5 & 320 & 756 & 134 \\
\hline G32-46 & $\mathrm{h}$ & 92.6 & 1.2 & 5 & 72 & 175 & 1.5 & 2.3 & 3.5 & 280 & 777 & 134 \\
\hline G34-54 & $\mathrm{h}$ & 92.9 & 0.9 & 43 & 38 & 133 & 0.6 & 0.3 & 1.6 & 191 & 706 & 128 \\
\hline G37-60 & $\mathrm{h}$ & 93.0 & 1.0 & 6 & 58 & 67 & 1.0 & 1.5 & 3.7 & 196 & 702 & 119 \\
\hline G38-63 & $\mathrm{h}$ & 93.3 & 0.9 & 1 & 69 & 64 & 1.0 & 0.2 & 3.4 & 125 & 685 & 115 \\
\hline G40-68 & $\mathrm{h}$ & 94.2 & 0.6 & 33 & 63 & 70 & 1.0 & 3.7 & 6.7 & 791 & 597 & 121 \\
\hline G50-84 & 1 & 91.5 & 1.0 & 71 & 39 & 376 & 1.1 & 11.6 & 5.8 & 284 & 929 & 163 \\
\hline G103-105 & $\mathrm{h}$ & 92.6 & 0.8 & 57 & 56 & 233 & 0.8 & 0.6 & 1.7 & 234 & 778 & 138 \\
\hline G103-106 & $\mathrm{h}$ & 92.6 & 1.3 & 27 & 53 & 173 & 0.9 & 0.6 & 1.5 & 165 & 703 & 129 \\
\hline G105-111 & $\mathrm{h}$ & 92.6 & 1.6 & 1 & 65 & 98 & 1.4 & 1.1 & 4.9 & 225 & 799 & 140 \\
\hline G106-113 & $\mathrm{h}$ & 93.6 & 1.0 & 31 & 92 & 93 & 1.5 & 9.6 & 3.5 & 419 & 646 & 126 \\
\hline G112-129 & $\mathrm{h}$ & 93.4 & 1.3 & 28 & 102 & 151 & 1.9 & 1.9 & 7.1 & 638 & 696 & 126 \\
\hline G112-129 & $\mathrm{h}$ & 93.4 & 1.1 & 21 & 70 & 147 & 1.8 & 2.3 & 2.4 & 337 & 711 & 127 \\
\hline G113-134 & 1-Ti & 92.9 & 1.2 & 115 & 108 & 383 & 1.3 & 33.1 & 8.6 & 446 & 662 & 127 \\
\hline G113-135 & 1-Ti & 92.7 & 1.1 & 112 & 116 & 370 & 2.1 & 34.8 & 9.0 & 443 & 709 & 139 \\
\hline G113-135 & 1-Ti & 92.7 & 0.9 & 115 & 123 & 416 & 1.4 & 33.8 & 9.3 & 450 & 717 & 135 \\
\hline G118-143 & $\mathrm{p}$ & 93.2 & 1.1 & 73 & 109 & 138 & 1.4 & 19.6 & 6.2 & 1043 & 698 & 122 \\
\hline G118-143 & $\mathrm{p}$ & 93.2 & 1.3 & 34 & 67 & 109 & 1.4 & 17.9 & 3.1 & 500 & 702 & 121 \\
\hline G119-145 & $\mathrm{p}$ & 92.8 & 1.3 & 33 & 89 & 256 & 0.9 & 2.1 & 6.8 & 499 & 827 & 158 \\
\hline G119-145 & $\mathrm{p}$ & 92.8 & 1.0 & 34 & 86 & 232 & 1.2 & 2.1 & 4.8 & 439 & 757 & 136 \\
\hline G120-147 & $\mathrm{p}$ & +93.3 & +1.9 & +83 & +90 & +146 & +0.9 & +5.2 & +15.5 & +1097 & +748 & +145 \\
\hline G120-147 & $\mathrm{p}$ & 93.3 & 1.8 & 30 & 61 & 146 & 1.4 & 5.4 & 2.8 & 382 & 710 & 131 \\
\hline G126-156 & $\mathrm{h}$ & 92.7 & 1.2 & 18 & 92 & 177 & 1.1 & 0.6 & 7.5 & 562 & 810 & 148 \\
\hline G126-158 & $\mathrm{h}$ & 93.1 & 1.2 & 16 & 75 & 167 & 1.3 & 0.5 & 4.6 & 281 & 739 & 132 \\
\hline G126-158 & $\mathrm{h}$ & 93.1 & 1.1 & 11 & 75 & 171 & 1.4 & 0.6 & 5.1 & 290 & 728 & 131 \\
\hline G127-160 & $\mathrm{p}$ & 93.8 & 1.0 & 15 & 67 & 125 & 1.6 & 2.6 & 1.2 & 156 & 698 & 125 \\
\hline G201-202 & 1-Ti & 90.3 & 2.8 & 94 & 94 & 563 & 2.6 & 71.7 & 10.0 & 399 & 1166 & 164 \\
\hline G202-205 & $\mathrm{h}$ & 93.4 & 1.4 & 4 & 13 & 34 & 0.5 & 0.2 & 0.7 & 118 & 721 & 146 \\
\hline G208-213 & $\mathrm{h}$ & 93.5 & 0.9 & 29 & 54 & 196 & 0.8 & 1.2 & 5.1 & 237 & 704 & 134 \\
\hline G209-217 & $\mathrm{h}$ & 92.7 & 1.4 & 27 & 47 & 133 & 0.8 & 0.9 & 5.1 & 361 & 710 & 128 \\
\hline G302-303 & $\mathrm{h}$ & 93.5 & 1.4 & 37 & 61 & 136 & 1.2 & 3.9 & 2.5 & 852 & 705 & 133 \\
\hline G303-304 & $\mathrm{h}$ & 93.5 & 0.9 & 16 & 23 & 63 & 0.7 & 0.5 & 3.5 & 380 & 659 & 123 \\
\hline G303-304 & $\mathrm{h}$ & 93.5 & 1.1 & 12 & 32 & 59 & 0.6 & 0.7 & 1.8 & 136 & 659 & 120 \\
\hline
\end{tabular}

All concentrations in $\mu \mathrm{g} / \mathrm{g}$. Fo = forsterite content of olivine (data for G30-40, G32-46, G37-60, G38-63 from Stachel and Harris 1997b). Inclusions with the same name as the row above indicate repeat analyses of the same grain. Inclusions with the same number in the sample name following the letter $\mathrm{G}$ are from the same diamond. The analysis marked with plus signs (G120-147) overlapped a healed microfracture

par. paragenesis: $l$ lherzolitic, $h$ harzburgitic, $p$ peridotitic, $l$-Ti Ti-rich lherzolite ca. $10 \times 15 \mu \mathrm{m}$ in diameter, i.e., many orders of magnitude larger) unless they are distributed highly heterogeneously. A Cr concentration map of inclusion G106-113 (Electronic Supplement; Fig. S4) does show considerable heterogeneity on a scale of $2-10 \mu \mathrm{m}$, which is consistent with the variability in EPMA and SIMS Cr data. The origin of this heterogeneity will be discussed later.

Healed micro-fractures in two olivine grains are distinctly different and show high contents of $\mathrm{Cr}, \mathrm{Ca}$ and $\mathrm{Al}$ as well as small bright spots in BSE imaging, presumably microinclusions of chromite.

\section{Garnet}

Major element compositions of garnets in this study were presented by Stachel and Harris (1997b) and are summarised here. The garnets show variable but high $\mathrm{Cr}_{2} \mathrm{O}_{3}$ contents (4.3-20.6 wt\%, Cr\# 0.13-0.66) and are some of the most 

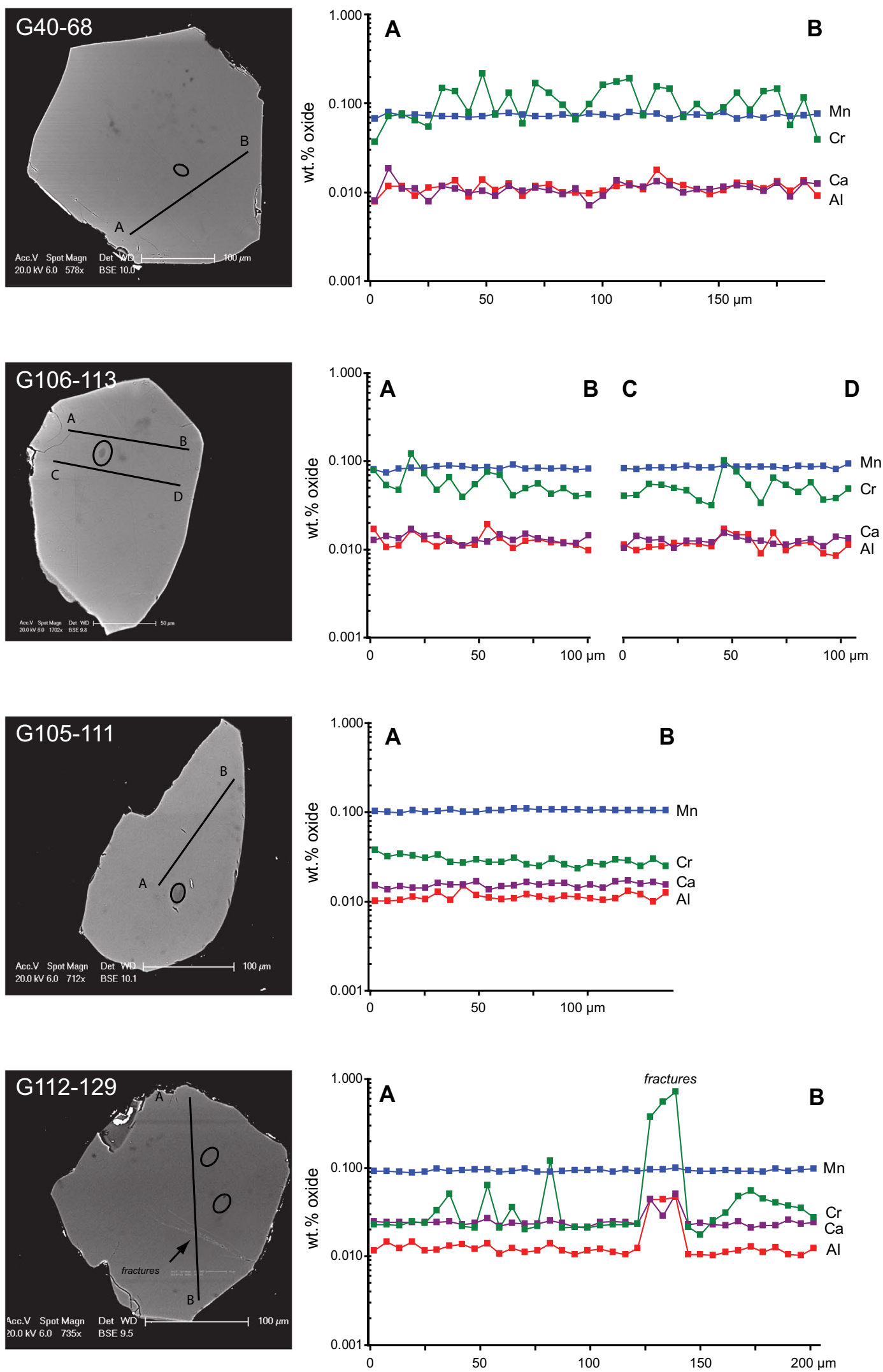
4Fig. 3 Concentration profiles (on a log scale) by EPMA of $\mathrm{Mn}, \mathrm{Cr}$, $\mathrm{Ca}$ and $\mathrm{Al}$ in selected olivine inclusions. The analytical uncertainty of each point is generally equal or smaller than the symbol size. Location of profiles are indicated in BSE images on the left, which also show the locations of ion microprobe pits. See also Fig. S4 in the electronic supplement for a high-precision $\mathrm{Cr}$ map of inclusion G106-113

$\mathrm{Cr}$-rich garnets reported in the literature. $\mathrm{Mg \#}$ range from 83.6 to $89.1 \%$. CaO contents are variable (1.0-6.3 wt \%) and 27 out of 32 garnets are subcalcic, i.e., these are harzburgitic or G10 garnets (Table 3). MnO contents span a relatively narrow range $(0.22-0.35 \mathrm{wt} \%)$ and show a positive correlation with $\mathrm{FeO}$.

Newly obtained trace element data (Table 3) show that Ti contents of garnets span an extremely wide range from 4 to $4600 \mu \mathrm{g} / \mathrm{g}$, although harzburgitic garnets all have $\mathrm{Ti}$ contents $<470 \mu \mathrm{g} / \mathrm{g}\left(<0.078 \mathrm{wt} \% \mathrm{TiO}_{2}\right)$. Scandium and V contents are high (130-560 $\mu \mathrm{g} / \mathrm{g}$ and 250-505 $\mu \mathrm{g} / \mathrm{g}$, respectively). Cobalt (40-48 $\mu \mathrm{g} / \mathrm{g}$ ) shows very little variation. A weak negative correlation exists between $\mathrm{V}$ and $\mathrm{Mg \#}$, as well as a weak positive correlation between $\mathrm{Sc}$ and $\mathrm{Cr}$, but no other elements show any correlation, including $\mathrm{V}$ and $\mathrm{Cr}$. Nickel contents range from 75 to $141 \mu \mathrm{g} / \mathrm{g}$.

\section{Geothermobarometry}

\section{Conventional major-element geothermobarometry}

Equilibrium pressures and temperatures of diamond-hosted inclusions at the time of their entrapment can be estimated based on the chemical composition of co-existing minerals in the same diamond, assuming that they were trapped simultaneously or at least under similar chemical and $P-T$ conditions, and that they are not touching other inclusions, in which case they would record the temperature of the mantle at the time of eruption (Phillips et al. 2004). All Akwatia inclusions reported here were non-touching, and for most diamonds it was possible to calculate temperature estimates, but pressure estimates could only be derived for the few diamonds that contained garnet-opx pairs or cpx, the only assemblages that can be reliably used as geobarometers. A summary of $P-T$ estimates is given in Table 4 . Note that equilibrium temperatures have been rounded to the nearest five degrees to reflect uncertainty in geothermometer calibrations and chemical analyses upon which the calculations are based. Most geothermobarometer calibrations have an accuracy of $15-30{ }^{\circ} \mathrm{C}$ and 2-3 kbar (e.g., Brey and Köhler 1990; Krogh 1988; Nimis and Taylor 2000). The estimated pressures and temperatures span the whole range of conditions expected for diamonds sampled along a $38-40 \mathrm{~mW} / \mathrm{m}^{2}$ conductive geotherm (Hasterok and Chapman 2011), i.e., from $1100{ }^{\circ} \mathrm{C}$ at $45 \mathrm{kbar}$ to $1300{ }^{\circ} \mathrm{C}$ at $65 \mathrm{kbar}$, and all fall within the diamond stability field, as required for inclusions in diamonds. We will now compare the results from various geothermobarometers in detail.

Simultaneous $P-T$ information could be obtained from seven single cpx inclusions (present in four of the studied diamonds; mineral data from Stachel and Harris 1997b). Using the single clinopyroxene geothermobarometer from Nimis and Taylor (2000), we obtained values of $T_{\mathrm{NT} 00}^{\mathrm{cpx}}=1185-1200{ }^{\circ} \mathrm{C}$ and $P_{\mathrm{NT} 00}^{\mathrm{cpx}}=53-54 \mathrm{kbar}$ for three pyroxenes (in two different diamonds, G50 and G201) and 1300-1310 ${ }^{\circ} \mathrm{C}$ at $59-60 \mathrm{kbar}$ for two others (in a single diamond, G23). Two anomalously K-rich cpx (0.7 wt\% $\mathrm{K}_{2} \mathrm{O}$ ) in a single diamond (G41) with no other inclusions gave relatively low $T_{\mathrm{NT} 00}^{\mathrm{cpx}}$ of $1150-1235^{\circ} \mathrm{C}$ at $58 \mathrm{kbar}$, but the high $\mathrm{K}_{2} \mathrm{O}$ contents are outside the calibration range of Nimis and Taylor (2000). Overall, the single-cpx results are about $50{ }^{\circ} \mathrm{C}$ cooler than the Kalahari geotherm of Rudnick and Nyblade (1999) and fall close to a $39 \mathrm{~mW} /$ $\mathrm{m}^{2}$ model conductive geotherm (Hasterok and Chapman 2011) (Fig. 4).

For cpx co-existing with garnet (in diamonds G50 and $\mathrm{G} 201)$, temperature estimates $\left(T_{\mathrm{Kr} 88}^{\mathrm{grt}-\mathrm{cpx}}\right)$ based on garnet-cpx $\mathrm{Mg}-\mathrm{Fe}$ exchange thermometry (Krogh 1988) are about $35^{\circ} \mathrm{C}$ cooler than $T_{\mathrm{NT} 00}^{\mathrm{cpx}}$ for both diamonds using the same $P_{\text {NT00 }}^{\mathrm{cpx}}$ barometer (i.e., agree within error, which are $\pm 25^{\circ} \mathrm{C}$ and $\pm 30{ }^{\circ} \mathrm{C}$ for $T_{\mathrm{Kr} 88}^{\mathrm{grt}-\mathrm{cpx}}$ and $T_{\mathrm{NT} 00}^{\mathrm{cpx}}$, respectively).

Two diamonds (G126 and G209) contained opx in addition to garnet and olivine; therefore, equilibration pressures could be calculated using Al-opx thermobarometry (Brey and Köhler 1990) combined with garnet-opx (Harley 1984) or garnet-olivine (O’Neill and Wood 1979) $\mathrm{Mg}-\mathrm{Fe}$ exchange thermometers (Fig. 4). For diamond G126, these thermometers give a wide range of temperatures $\left(T_{\text {Ow79 }}^{\text {grt-ol }}=1150-1280{ }^{\circ} \mathrm{C}, T_{\mathrm{Ha} 84}^{\text {grt-opx }}=1160-1185^{\circ} \mathrm{C}\right)$, which renders the pressure estimate rather uncertain $\left(P_{\mathrm{BKN}}^{\mathrm{Al}-\mathrm{opx}}=50-61 \mathrm{kbar}\right)$. As the two olivine inclusions in this diamond have quite different compositions (Table 2), one or both of these are not in equilibrium with co-existing opx and garnet. Indeed, if we ignore olivine G126-156, $T_{\mathrm{Ow}}^{\text {grt-ol }}$ results $\left(1150-1180{ }^{\circ} \mathrm{C}\right)$ are much closer to $T_{\mathrm{Ha}}^{\text {grt-opx }}$ and $P_{\mathrm{BKN}}^{\mathrm{Al}-\mathrm{opx}}=50-53 \mathrm{kbar}$. For diamond G209, $T_{\mathrm{OW}}^{\text {grt-ol }}$ and $T_{\mathrm{Ha} 4}^{\text {grt-opx }}$ differ by $55{ }^{\circ} \mathrm{C}$ (i.e., agree within error due to the larger uncertainties of these geothermometers of $60{ }^{\circ} \mathrm{C}$ and $40{ }^{\circ} \mathrm{C}$, respectively), resulting in a $P_{\mathrm{BKN}}^{\mathrm{Al}-\mathrm{opx}}$ estimate of 50-55 kbar.

Two more diamonds contained garnet and opx but no olivine. Diamond G104 contained single garnet and opx inclusions giving a $P_{\mathrm{BKN}}^{\mathrm{Al}-\mathrm{opx}}$ at $T_{\mathrm{Ha} 84}^{\mathrm{grt}-\mathrm{opx}}$ estimate of $1210{ }^{\circ} \mathrm{C}$ at 58 kbar. Diamond G111 contained two garnets and three opx, which resulted in an wide range of $P-T$ estimates (1160-1450 ${ }^{\circ} \mathrm{C}$ and $\left.43-78 \mathrm{kbar}\right)$ due to the range in $\mathrm{Al}_{2} \mathrm{O}_{3}$ contents in three co-existing opx (0.92-1.19 wt\%). As the Mg\# of the two garnet inclusions was also significantly different (Mg\# 89.9 vs. 90.3), inclusions in this 
Table 3 Trace-element concentrations of garnet inclusions by SIMS

\begin{tabular}{|c|c|c|c|c|c|c|c|c|c|}
\hline Garnet & Mg\# & $\mathrm{Cr} \#$ & Ca_int & Grt type & $\mathrm{Ti}$ & $\mathrm{Ni}$ & Sc & V & Co \\
\hline G29-39 & 0.88 & 0.26 & 0.86 & G10 & 52 & 119 & 166 & 335 & 47 \\
\hline G30-42 & 0.85 & 0.29 & 1.99 & G10 & 243 & 104 & 161 & 426 & 47 \\
\hline G31-45 & 0.88 & 0.28 & 0.79 & G10 & 65 & 141 & 174 & 378 & 47 \\
\hline G32-48 & 0.88 & 0.34 & 1.13 & G10 & 115 & 116 & 251 & 293 & 45 \\
\hline G33-50 & 0.87 & 0.16 & 1.73 & G10 & 4 & 79 & 157 & 346 & 44 \\
\hline G33-51 & 0.87 & 0.15 & 1.71 & G10 & 4 & 81 & 167 & 332 & 44 \\
\hline G34-53 & 0.87 & 0.29 & 1.96 & G10 & 19 & 90 & 227 & 308 & 44 \\
\hline G35-57 & 0.87 & 0.16 & 1.72 & G10 & 4 & 82 & 174 & 345 & 45 \\
\hline G37-61 & 0.87 & 0.44 & 0.64 & G10 & 87 & 103 & 423 & 309 & 47 \\
\hline G38-65 & 0.87 & 0.30 & 0.68 & G10 & 7 & 88 & 272 & 305 & 45 \\
\hline G40-67 & 0.86 & 0.40 & 0.96 & G10 & n.a. & n.a. & n.a. & n.a. & n.a. \\
\hline G50-82 & 0.84 & 0.20 & 4.50 & G9 & 1325 & 90 & 216 & 394 & 45 \\
\hline G50-85 & 0.83 & 0.21 & 4.23 & G9 & 1430 & 91 & 203 & 433 & 45 \\
\hline G103-103 & 0.87 & 0.16 & 2.05 & G10 & 21 & 94 & 156 & 312 & 44 \\
\hline G103-104 & 0.88 & 0.16 & 2.03 & G10 & 22 & 92 & 156 & 344 & 41 \\
\hline G104-107 & 0.88 & 0.18 & 3.14 & G10 & n.a. & n.a. & n.a. & n.a. & n.a. \\
\hline G105-109 & 0.87 & 0.34 & 0.84 & G10 & 92 & 98 & 248 & 342 & 45 \\
\hline G106-112 & 0.89 & 0.24 & 0.62 & G10 & 450 & 130 & 141 & 326 & 46 \\
\hline G107-114 & 0.88 & 0.31 & 0.73 & G10 & 61 & 99 & 377 & 149 & 44 \\
\hline G111-122 & 0.88 & 0.23 & 0.45 & G10 & n.a. & n.a. & n.a. & n.a. & n.a. \\
\hline G111-123 & 0.88 & 0.25 & 0.46 & G10 & n.a. & n.a. & n.a. & n.a. & n.a. \\
\hline G112-127 & 0.89 & 0.31 & 0.91 & G10 & 94 & 124 & 199 & 292 & 44 \\
\hline G112-128 & 0.89 & 0.30 & 0.92 & G10 & 101 & 123 & 214 & 313 & 44 \\
\hline G113-132 & 0.87 & 0.16 & 3.80 & G11 & 2259 & 98 & 137 & 330 & 41 \\
\hline G113-133 & 0.87 & 0.15 & 3.87 & G11 & 2182 & 97 & 130 & 320 & 41 \\
\hline G126-154 & 0.88 & 0.29 & 1.39 & G10 & 29 & 104 & 232 & 352 & 44 \\
\hline G126-155 & 0.87 & 0.29 & 1.37 & G10 & 29 & 108 & 232 & 337 & 45 \\
\hline G201-203 & 0.84 & 0.13 & 4.47 & G11 & 4583 & 125 & 256 & 475 & 44 \\
\hline G202-204 & 0.86 & 0.46 & 0.70 & G10 & 31 & 92 & 217 & 506 & 46 \\
\hline G208-214 & 0.88 & 0.35 & 2.14 & G10 & 280 & 90 & 241 & 338 & 40 \\
\hline G209-216 & 0.86 & 0.32 & 1.53 & G10 & n.a. & n.a. & n.a. & n.a. & n.a. \\
\hline G302-302 & 0.88 & 0.51 & 0.95 & G10 & 242 & 123 & 236 & 284 & 44 \\
\hline G303-305 & 0.86 & 0.66 & 0.62 & G10 & 28 & 128 & 234 & 375 & 45 \\
\hline G304-308 & 0.87 & 0.35 & 0.97 & G10 & 214 & 87 & 383 & 248 & 45 \\
\hline G305-309 & 0.88 & 0.22 & 1.26 & G10 & 464 & 105 & 186 & 331 & 45 \\
\hline G306-311 & 0.88 & 0.24 & 0.50 & G10 & 111 & 100 & 167 & 271 & 47 \\
\hline G307-313 & 0.86 & 0.32 & 1.87 & G10 & 45 & 75 & 330 & 349 & 44 \\
\hline
\end{tabular}

Trace elements by SIMS in $\mu \mathrm{g} / \mathrm{g}$, other chemical data based on EPMA (previously published in Stachel and Harris 1997b): $\mathrm{Mg} \#=$ atomic $\mathrm{Mg} /(\mathrm{Mg}+\mathrm{Fe}), \mathrm{Cr} \#=$ atomic $\mathrm{Cr} /(\mathrm{Cr}+\mathrm{Al}), \mathrm{Ca} \_$int $(\mathrm{CaO}$ intercept value $)$ indicates how far a garnet is removed from the harzburgite-lherzolite division $\left(\mathrm{Ca} \_\right.$int $\left.=3.375\right)$ after Grütter et al. (2004). Garnet types: $G 10$ harzburgitic, G9 lherzolitic, $G 11$ high-Ti lherzolitic (Grütter et al. 2004). Inclusions with the same number in the sample name following the letter $G$ are from the same diamond n.a. not analyzed

particular diamond are clearly not syngenetic, but were trapped at different times in a chemically/physically evolving environment.

For all other diamonds, only temperatures could be estimated due to the lack of cpx and opx. The most common co-existing mineral pair is garnet-olivine. $T_{\text {OW79 }}^{\text {grt-l }}$ results for garnet and olivine inclusions range from 975 to $1440{ }^{\circ} \mathrm{C}$ at a fixed pressure of $55 \mathrm{kbar}$, and most cluster around $1100-1300{ }^{\circ} \mathrm{C}$ (average $1210^{\circ} \mathrm{C}$ ). In general, if multiple garnets and/or olivines were present within a diamond, they fall within $50{ }^{\circ} \mathrm{C}$ with only a few exceptions. An updated calibration of the garnet-olivine $\mathrm{Fe}-\mathrm{Mg}$ exchange thermometer 
Table 4 Pressure-temperature estimates

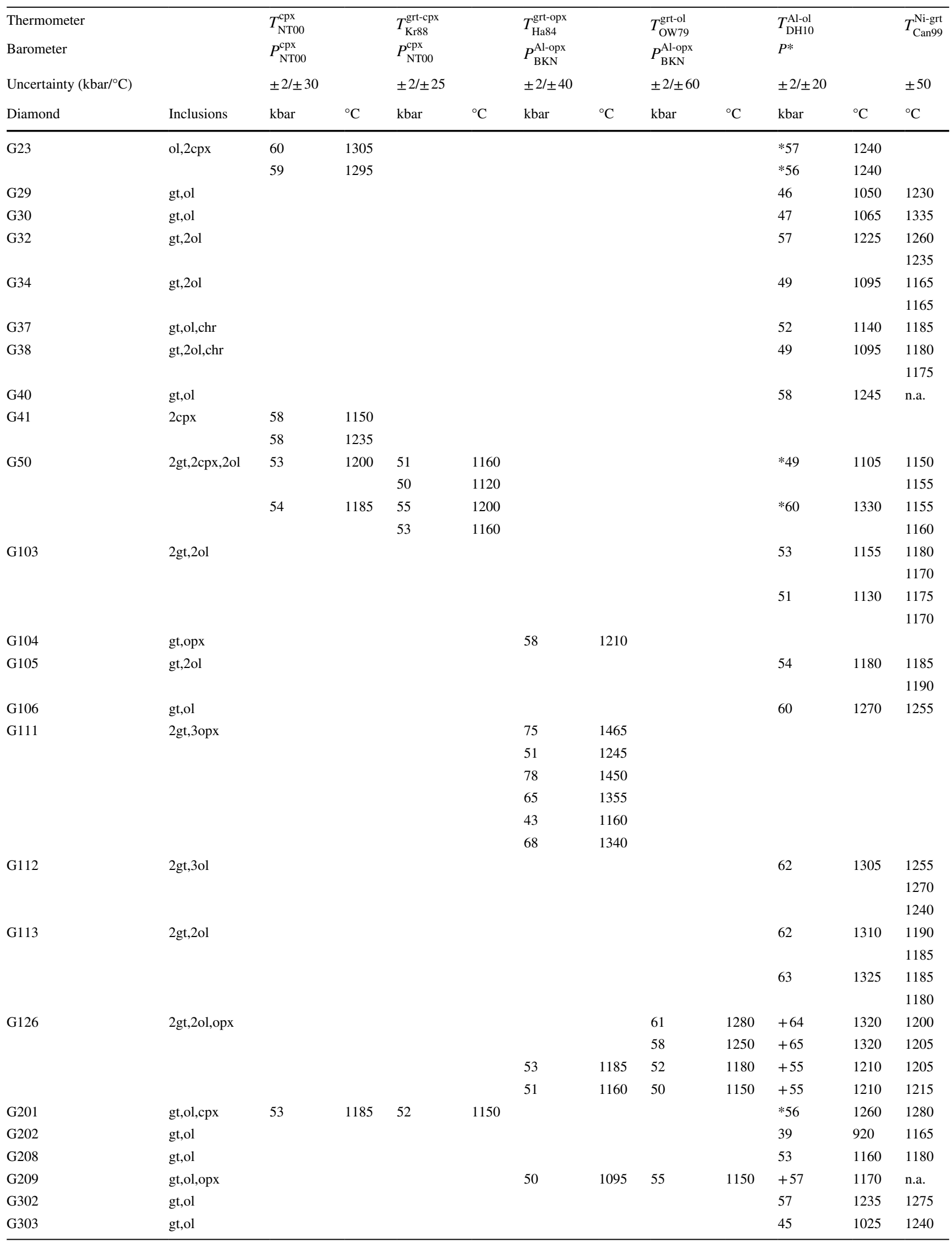


Table 4 (continued)

Temperatures rounded to the nearest $5{ }^{\circ} \mathrm{C} . P^{*}: T_{\mathrm{Al}-\mathrm{ol}}$ with either $P_{\mathrm{NT} 00}\left(\right.$ marked $*$ ) or $P_{\mathrm{BKN}}$ for pressure estimate $($ marked + ), or transposed onto $39 \mathrm{~mW} / \mathrm{m}^{2}$ conductive geotherm

n.a. not analysed

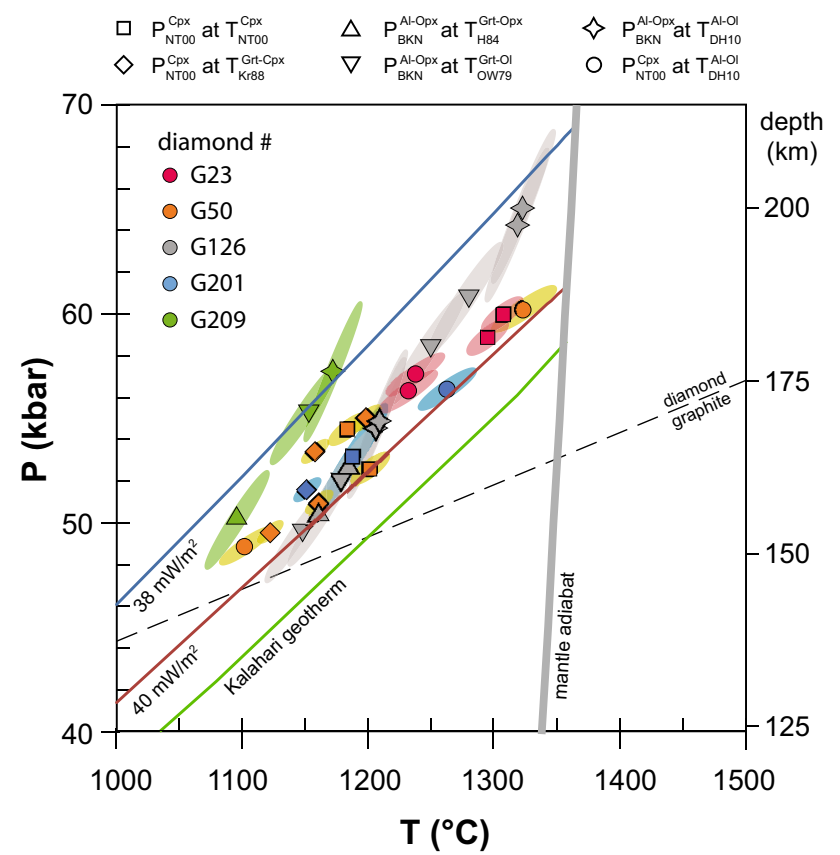

Fig. 4 Estimated $P-T$ equilibration conditions of silicate inclusions in Akwatia diamonds colour-coded by diamond specimen whereas different symbols represent different geothermobarometer combinations (see Table 4 for data and abbreviations, note that only diamonds with olivine inclusions have been plotted). Error ellipses represent 95\% confidence intervals of analytical uncertainties propagated through geothermobarometrical equations. Also plotted are the Kalahari geotherm and convective mantle adiabat of Rudnick and Nyblade (1999), 38 and $40 \mathrm{~mW} / \mathrm{m}^{2}$ conductive geotherms (Hasterok and Chapman 2011), and the diamond-graphite transition (Kennedy and Kennedy 1976)

by $\mathrm{Wu}$ and Zhao (2007) resulted in similar temperatures within $50{ }^{\circ} \mathrm{C}$.

In conclusion, where $P$ and/or $T$ estimates could be derived from multiple inclusions in a single diamond, these estimates generally agree within uncertainty of the geothermobarometer calibrations. A few inclusions are clearly anomalous, as they result in anomalous $P-T$ estimates (e.g., olivine G126-156, and all three opx inclusions in diamond G111), which indicates these were not in equilibrium with the other inclusions in the host diamond, so were trapped in an evolving chemical environment and/or at different $P-T$ conditions.

\section{Ni in garnet thermometry}

Estimates of equilibrium temperatures for garnets can be obtained from their $\mathrm{Ni}$ contents assuming equilibrium with mantle olivine (Canil 1999a; Griffin et al. 1989; Ryan et al. 1996), which is the case for all garnet inclusions presented here. Depending on the calibration used, temperatures range from 1175 to $1480{ }^{\circ} \mathrm{C}$ (Ryan et al. 1996 calibration) or $1115-1335{ }^{\circ} \mathrm{C}$ (Canil 1999a calibration). These ranges are smaller than the range obtained by grt-olivine $\mathrm{Mg}-\mathrm{Fe}$ exchange thermometry, but extend to higher $\mathrm{T}$ for the Ryan et al. (1996) calibration. Temperature estimates for multiple garnets within a single diamond generally agree within $25{ }^{\circ} \mathrm{C}$, compared to an uncertainty of the thermometers of $\pm 50{ }^{\circ} \mathrm{C}$ (Ryan et al. 1996; Canil 1999a).

The discrepancy between the two Ni-grt calibrations has been reported in the literature before, but has not been resolved (Canil 1996; Griffin and Ryan 1996). One possibility is that the difference is due to the Ryan et al. (1996) calibration not taking variation of $\mathrm{Ni}$ contents of co-existing olivine into account. As Ni contents of Akwatia olivines are higher than average mantle (Stachel and Harris 1997a), this may have introduced a bias towards higher temperatures. However, even when taking the differences in Ni contents into account (3140 and $2900 \mu \mathrm{g} / \mathrm{g} \mathrm{Ni}$, respectively), the two calibrations still differ by ca $75^{\circ} \mathrm{C}$. As $T_{\mathrm{Can} 99}^{\mathrm{Ni}}$ has negligible pressure dependence (Canil 1999a), uncertainty in equilibrium pressure cannot explain the difference. Because Ryan et al. (1996) estimates resulted in temperatures for several garnets that were well above the mantle adiabat and thus unreasonably high, and the Canil (1999a) estimates agree best with major-element-based $P-T$ estimates (see previous section), we used the latter calibration in the remainder of this study.

\section{Trace element thermometry of olivine}

Aluminium, $\mathrm{Cr}$ and $\mathrm{Ca}$ in olivine have been calibrated as single-mineral geothermobarometers for garnet-bearing peridotites (Bussweiler et al. 2017; De Hoog et al. 2010; Köhler and Brey 1990). However, the calibrations only involved lherzolitic assemblages and were not tested on cpx-free rocks with subcalcic garnets. This could potentially lead to inaccuracies, particularly for $\mathrm{Ca}$, as the activity of this element is no longer buffered by a Ca-saturated co-existing phase, which is essential for the accuracy of single-mineral geothermometers (De Hoog et al. 2010). In 


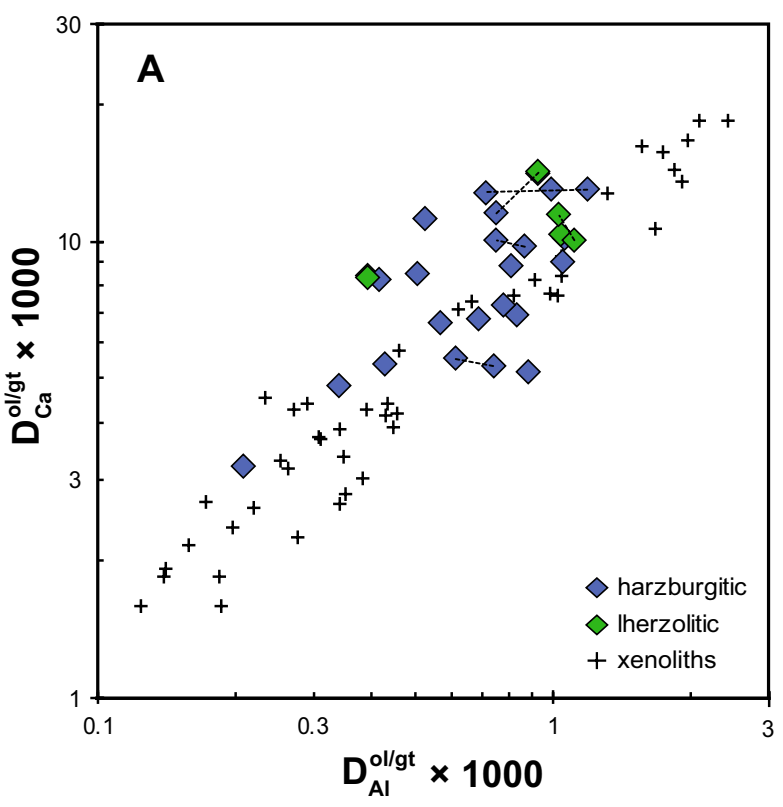

Fig. 5 Diagram of a $D_{\mathrm{Ca}}^{\mathrm{ol} / \mathrm{grt}}$ vs. $D_{\mathrm{Al}}^{\mathrm{ol} / \mathrm{grt}} ; \mathbf{b} D_{\mathrm{Al}}^{\mathrm{ol} / \mathrm{grt}}$ vs. equilibration temperature $\left[1000 / T_{\text {Canil }}^{\mathrm{Ni} \text {-grt }}(\mathrm{K})\right]$ for Al. Plus symbols represent mantle xenolith data from De Hoog et al. (2010), for which no $T_{\text {Canil }}^{\mathrm{Ni} \text { grt }}$ was

addition, $\mathrm{Cr}_{2} \mathrm{O}_{3}$ contents of Akwatia garnets are on average much higher, and thus $\mathrm{Al}_{2} \mathrm{O}_{3}$ contents lower, than those used for calibration of the Al-ol thermometer (De Hoog et al. 2010). Even though the Al-ol thermometer has a correction for $\mathrm{Cr} \#$, its validity has not been tested using the high Cr\# observed in this study (0.47-0.90 compared to $0.33-0.75$ in the mantle xenolith database). Therefore, we compared $T_{\mathrm{DH} 10}^{\mathrm{Al}-\mathrm{ol}}$ and $T_{\mathrm{DH} 10}^{\mathrm{Ca}-\mathrm{l}}$ (De Hoog et al. 2010) using (1) measured $\mathrm{Ca}$ and $\mathrm{Al}$ contents, with (2) using $\mathrm{Ca}$ and $\mathrm{Al}$ corrected for the deviation of $\mathrm{CaO}$ and $\mathrm{Al}_{2} \mathrm{O}_{3}$ of co-existing garnets from average $\mathrm{CaO}$ and $\mathrm{Al}_{2} \mathrm{O}_{3}$ in garnet from the calibration of De Hoog et al. (2010) (e.g., $\mathrm{Ca}_{\text {corr }}=\mathrm{Ca}_{\mathrm{ol}} /$ $\mathrm{CaO}_{\text {grt }} \times \mathrm{CaO}_{\text {avg }}$, where $\mathrm{CaO}_{\text {grt }}=\mathrm{CaO}$ (wt\%) in co-existing garnet and $\mathrm{CaO}_{\text {avg }}=$ average $\mathrm{CaO}(\mathrm{wt} \%)$ of garnet used in $T_{\mathrm{DH} 10}^{\mathrm{Ca}-\mathrm{ol}}$ calibration, which was $5.02 \mathrm{wt} \%$ ). Note that the $\mathrm{Al}_{2} \mathrm{O}_{3}$ content of garnet is inversely correlated with its $\mathrm{Cr}_{2} \mathrm{O}_{3}$ content. As the $T_{\mathrm{DH} 10}^{\mathrm{Al}-\mathrm{ol}}$ formulation also incorporates a Cr\# correction, we used the Al-ol formulation without Cr\# correction from Eq. 13 in De Hoog et al. (2010) to avoid incorporating the effect of $\mathrm{Cr} \#$ twice.

When using a fixed pressure of $55 \mathrm{kbar}$, the range of $T_{\mathrm{DH} 10}^{\mathrm{Al} 10}$ is $1005-1295^{\circ} \mathrm{C}$ with an average of $1195^{\circ} \mathrm{C}$. After correcting for garnet $\mathrm{Al}_{2} \mathrm{O}_{3}$ content, the range is a little smaller $\left(1045-1280^{\circ} \mathrm{C}\right)$ and the average is slightly higher $\left(1205^{\circ} \mathrm{C}\right)$, but well within the uncertainty of the thermometer, which is $\pm 20^{\circ} \mathrm{C}$ (De Hoog et al. 2010). This indicates that the effect of high $\mathrm{Cr}$ contents of garnet on $T_{\mathrm{DH} 10}^{\mathrm{Al} 10}$ is negligible. For $T_{\mathrm{DH} 10}^{\mathrm{Ca} 1 \mathrm{O}}$ the range is $980-1370{ }^{\circ} \mathrm{C}$ with an average of

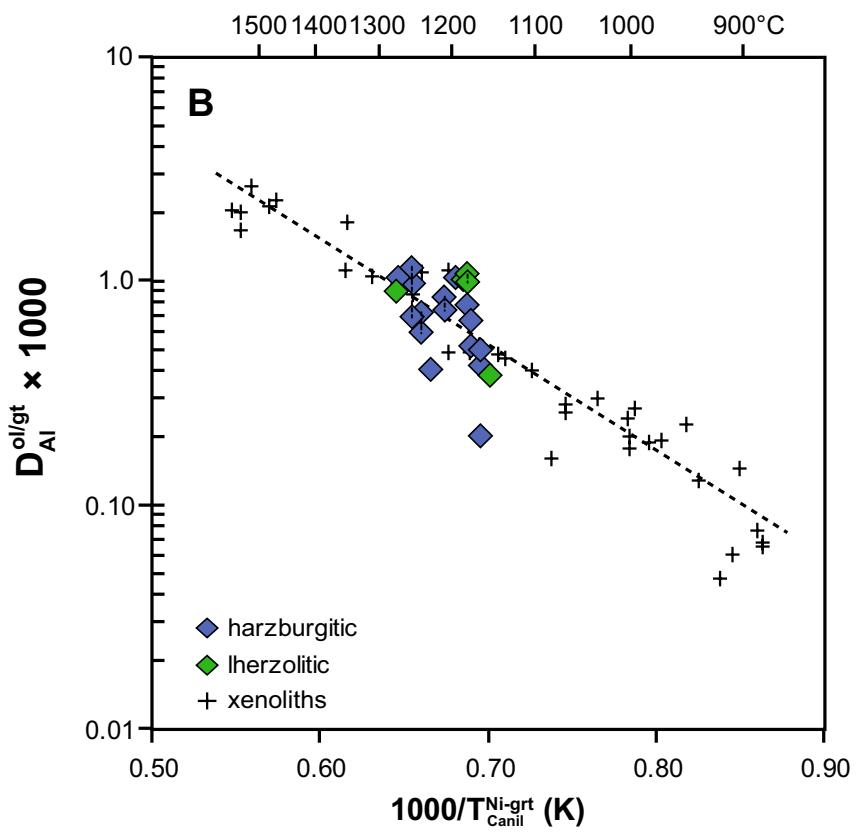

available, so $T_{\mathrm{BKN}}^{\mathrm{cpx}-\mathrm{opx}}$ was used instead. Symbols connected by stippled lines indicate multiple analyses of the same inclusion

$1160{ }^{\circ} \mathrm{C}$. If the thermometer is corrected for $\mathrm{CaO}$ content of garnet, the range is much reduced $\left(1115-1350{ }^{\circ} \mathrm{C}\right)$ and the average is considerably higher $\left(1255^{\circ} \mathrm{C}\right)$. Thus, $\mathrm{Ca}-\mathrm{ol}$ temperatures without correction are significantly biased towards low temperatures, but after correction they are higher than $T_{\mathrm{DH} 10}^{\mathrm{Al} \text { lol }}$. As $T_{\mathrm{DH} 10}^{\mathrm{Al}-\mathrm{ol}}$ and $T_{\mathrm{DH} 10}^{\mathrm{Ca} 10}$ have different $P$ sensitivities, this difference could be due to the arbitrary $P$ taken for this comparison. However, the difference is also visible when $P$ can be calculated, as in two harzburgitic diamonds (G209 and G126) in which olivine co-exists with garnet and opx. In diamond $\mathrm{G} 209, \mathrm{Al}$ and $\mathrm{Ca}$ in olivine lead to $P-T$ estimates of $1170{ }^{\circ} \mathrm{C}$ at $57 \mathrm{kbar}$ and $1520{ }^{\circ} \mathrm{C}$ at $93 \mathrm{kbar}$, respectively. In diamond G126, in which two pairs each of garnets and olivines were present, there is a considerable range in $T_{\mathrm{DH} 10}^{\mathrm{Al}-\mathrm{ol}}$ at $P_{\mathrm{BKN}}^{\mathrm{Al}-\mathrm{opx}}\left(1205-1320^{\circ} \mathrm{C}\right.$ and 55-65 kbar) and an equally large range in $T_{\mathrm{DH} 10}^{\mathrm{Ca}-\mathrm{l}}$ at $P_{\mathrm{BKN}}^{\mathrm{Al}-\mathrm{Cpx}}\left(1475-1620^{\circ} \mathrm{C}\right.$ and 79-94 kbar). This suggests not only that not all inclusions in the latter diamond were in equilibrium, as was already shown in the section on traditional geothermometry, but also that $T_{\mathrm{DH} 10}^{\mathrm{Ca} \text { ol }}$ estimates for both diamonds are unreasonably high.

Anomalously high $\mathrm{Ca}$ contents in olivine are also indicated by a plot of $D_{\mathrm{Al}}^{\mathrm{ol} / \mathrm{gt}}$ vs. $D_{\mathrm{Ca}}^{\mathrm{ol} / \mathrm{gt}}$ (Fig. 5a). Both these parameters are similarly sensitive to temperature, so one would expect these to correlate strongly. This is indeed the case for lherzolitic mantle xenoliths (De Hoog et al. 2010), but many Akwatia olivine inclusions fall towards the high $\mathrm{Ca} /$ Al side, and will, therefore, show too high $T_{\mathrm{DH} 10}^{\mathrm{Ca}-\mathrm{l}}$ values. 
This latter may be due to the $\mathrm{CaO}$ correction for subcalcic garnets being inaccurate (i.e., equilibration temperature is not linearly correlated with $D_{\mathrm{Ca}}^{\mathrm{ol} / \mathrm{gt}}$ ), but we note that several lherzolitic inclusions (which avoid the calibration issues mentioned above) also plot above the mantle lherzolites array. In addition, comparison of $T_{\mathrm{DH} 10}^{\mathrm{Ca} 10}$ with the single cpx thermobarometer ( $T_{\mathrm{NT} 00}^{\mathrm{cpx}}$; Nimis and Taylor 2000) also gives inconsistent results.

Therefore, we suspect the high $\mathrm{Ca} / \mathrm{Al}$ olivines were affected by transient heating events at the time of their entrapment in the diamond. Calcium diffuses faster than $\mathrm{Al}$ and during heating, $\mathrm{Ca}$ will diffuse into the olivine, resulting in Ca zoning with increasing concentrations towards the olivine rim (Köhler and Brey 1990). When these zoned olivines are trapped in diamond, they would homogenise due to diffusion during storage in the mantle, but cannot re-equilibrate with other silicate minerals. This would result in high $\mathrm{Ca} / \mathrm{Al}$ ratios and anomalous $T_{\mathrm{DH} 10}^{\mathrm{Ca}-\mathrm{l}}$ values.

In summary, the Cr\# correction of $T_{\mathrm{DH} 10}^{\mathrm{Al}-\mathrm{l}}$ is valid for the high Cr\# of garnet and olivine in the Akwatia suite, and this single-element thermometer can be used reliably for diamond inclusion suites. However, Ca-based geothermobarometers (De Hoog et al. 2010; Köhler and Brey 1988) should only be applied to olivine inclusions in diamonds that are undoubtedly of lherzolitic paragenesis (see "Discussion" for criteria), but, as shown above, even for those samples, results are often still unreliable.

\section{Comparison between major and trace-element based geothermometers}

Nickel in garnet temperatures show very little correlation with $\mathrm{Mg}-\mathrm{Fe}$ exchange garnet-olivine temperatures, despite both thermometers being based on the same mineral pairs. Only about half the values fall within $50{ }^{\circ} \mathrm{C}$ of each other. The $T_{\text {OW79 }}^{\text {grt-ol }}$ range is much larger than the $T_{\text {Can99 }}^{\mathrm{Ni} \text {-grt }}$ range (460 vs. $220{ }^{\circ} \mathrm{C}$, respectively) and several values of $T_{\mathrm{OW} 79}^{\mathrm{grt}-\mathrm{l}}$ are outside the diamond stability field $\left(<1050{ }^{\circ} \mathrm{C}\right)$ or above the mantle adiabat $\left(>1360^{\circ} \mathrm{C}\right)$, indicating that these $T$ estimates are unreliable. Only the average of both thermometers agrees well $\left(1215^{\circ} \mathrm{C}\right.$ and $1210^{\circ} \mathrm{C}$, respectively), but for $T_{\text {OW79 }}^{\text {grt-ol }}$ this value is dependent on the pressure assumed in the calibration (55 kbar in this study).

There are several possible explanations for the discrepancies between $T_{\mathrm{OW}}^{\mathrm{grt}-\mathrm{ol}}$ and $T_{\mathrm{Can} 99}^{\mathrm{Ni} \text {. }}$. Both methods assume equilibrium between garnet and olivine inclusions from the same diamond, whereas in reality they may have become encapsulated during different stages in the growth of their host diamond that were associated with fluctuations in the chemical environment or formation temperature. As Ti contents of garnet and olivine correlate well (Fig. 7), the assumption of equilibrium appears justified, but geothermometers are highly sensitive to small variations in concentrations of the elements involved, so even when minerals appear to be close to equilibrium, they may still yield erroneous temperatures. Also, due to differences in their diffusivities, some elements may be in equilibrium, whereas others are not.

A further thermometer based on equilibrium between garnet and olivine is $\mathrm{T}_{\mathrm{Al}-\mathrm{ol}}$. Figure $5 \mathrm{~b}$ shows $T_{\mathrm{Can} 99}^{\mathrm{Ni} \text {-grt }}$ of the inclusions vs. $D_{\mathrm{Al}}^{\mathrm{ol} / \mathrm{gt}}$. Overall, the olivine inclusions plot near the mantle xenolith trend (based on conventional geothermobarometry of four-phase lherzolites; De Hoog et al. 2010), but the correlation between $D_{\mathrm{Al}}^{\mathrm{ol} / \mathrm{gt}}$ and $T_{\mathrm{Can} 99}^{\mathrm{Ni}-\mathrm{grt}}$ is poor. Some of the scatter is derived from heterogeneous distribution of $\mathrm{Al}$ in several olivines (Fig. 3), but this does not explain the full extent of the range in $D_{\mathrm{Al}}^{\mathrm{ol} / \mathrm{gt}}$ at constant $T_{\mathrm{Can} 99}^{\mathrm{Ni} \text {.grt }} . D_{\mathrm{Ca}}^{\mathrm{ol} / \mathrm{gt}}$ vs. $T_{\mathrm{Can} 99}^{\mathrm{Ni} \text {-grt }}$ (not plotted) shows a similar scatter as $D_{\mathrm{Al}}^{\mathrm{ol} / \mathrm{gt}}$.

In summary, even though most geothermobarometers give similar pressure-temperature ranges on average, correlation between different calibrations is poor. This is partially due to either inaccuracies based on calibrations potentially not being applicable to harzburgitic paragenesis inclusions (e.g., $\left.T_{\mathrm{DH} 10}^{\mathrm{Ca}-\mathrm{ol}}\right)$ or large uncertainties associated with some of the calibrations (e.g., $T_{\mathrm{OW} 79}^{\mathrm{grt}-\mathrm{ol}}$ ). However, discrepancies exceed expectations even taking these factors into account. In some instances, the main factor appears to be disequilibrium between mineral inclusions in the same diamond, which suggest that the diamonds grew in an environment with evolving $P-T$ conditions and/or chemistry (e.g., Bulanova 1995). From this perspective, single-mineral calibrations (cpx; $P_{\mathrm{NT} 00}^{\mathrm{cpx}}$ at $\left.T_{\mathrm{NT} 00}^{\mathrm{cpx}}\right)$ or calibrations that are only weakly reliant on co-existing mineral composition (e.g., $T_{\mathrm{Can} 99}^{\mathrm{Ni}}, T_{\mathrm{DH} 10}^{\mathrm{Al} 1 \mathrm{ol}}$ ) are therefore preferable when studying diamond inclusion suites.

\section{Thermal structure of diamond source mantle}

Taking into account the uncertainties in geothermometry results discussed earlier, the Akwatia dataset can be used to provide constraints on the thermal structure of the mantle beneath the West Africa Craton at the time of diamond formation $(>2.2 \mathrm{Ga})$. In total, five diamonds were available for which pressure estimates could be calculated (opx or cpx present), and six different thermometer-barometer combinations were used to calculate $P-T$ estimates (Fig. 4). When multiple inclusions of the same type were present, separate $P-T$ estimates were calculated for each inclusion. Considerable scatter is observed, with variation in $T$ estimates for single diamonds ranging from 100 up to $300{ }^{\circ} \mathrm{C}$, whereas the minimum pressure variation is $4 \mathrm{kbar}$, but can be as high as $16 \mathrm{kbar}$. Some of the variation may be explained by uncertainty in the $P-T$ calculations, which can be large especially for pressure-sensitive thermometers (e.g., $\left.T_{\mathrm{DH} 10}^{\mathrm{Al}-\mathrm{ll}}\right)$ and temperature-sensitive barometers (e.g., $\left.P_{\mathrm{BKN}}^{\mathrm{Al}-\mathrm{opx}}\right)$. The 
propagated analytical uncertainties (not considering errors inherent in the calibration of the used geothermobarometers) are indicated in Fig. 4 by error ellipses, and even with our high-precision EPMA data, this can lead to uncertainty in pressure estimates of up to $10 \mathrm{kbar}$. Due to its low temperature sensitivity, $P_{\mathrm{NT} 00}^{\mathrm{cpx}}$ gives much smaller uncertainties on individual $P-T$ calculations than other geobarometers, but like other geothermometers gives inconsistent results; the $P-T$ range for each diamond using $P_{\mathrm{NT} 00}^{\mathrm{cpx}}$ is no smaller than when using $P_{\mathrm{BK} 90}$ estimates.

Nevertheless, several observations can be made. First, as one would expect, all $P-T$ estimates fall within the diamond stability field. Second, the paleogeotherm of the West Africa Craton is somewhat cooler than the Kalahari geotherm (based on the Kaapvaal and Zimbabwe cratons; Rudnick and Nyblade 1999) and scatters around $38-40 \mathrm{~mW} / \mathrm{m}^{2}$ conductive geotherms (Hasterok and Chapman 2011), in agreement with the smaller dataset from Stachel and Harris (1997b). This scatter could reflect actual temporal or spatial variations in heat flow beneath the West Africa Craton, but note that several diamonds (G50, G201) cover nearly the whole range of heat flow estimates. Third, the diamonds of the Akwatia field were derived from a continuous mantle section from the diamond-graphite boundary (ca. 140-km depth) down to ca. $200 \mathrm{~km}$. This latter depth is the expected thickness of the lithosphere for a heat flow of 38-39 mW/m² (Hasterok and Chapman 2011).

Similar estimates can be derived from olivine data alone, as $T_{\mathrm{DH} 10}^{\mathrm{Al} \text { ol }}$ is insensitive to mantle lithology and gives similar results to other geothermometers. However, $T_{\mathrm{DH} 10}^{\mathrm{Al}-\mathrm{ol}}$ alone does not give an accurate $P-T$ estimate. $\mathrm{P}_{\mathrm{KB} 90}^{\mathrm{Ca}-0 l}$ has been calibrated as a geobarometer (Köhler and Brey 1990; De Hoog et al. 2010), but combining this with $T_{\mathrm{DH} 10}^{\mathrm{Al}-\mathrm{l}}$ gives unreasonably large uncertainties due to the shallow intercept of the two geothermobarometers in $P-T$ space. As an alternative, for sufficiently large suites of diamond-hosted olivines the range of $T_{\mathrm{DH} 10}^{\mathrm{Al}-\mathrm{ol}}$ values can be used to determine the thermal state of the mantle at the time of olivine entrapment. Essentially, by calculating $T_{\mathrm{DH} 10}^{\mathrm{Al}-\mathrm{l}}$ using pressure from a certain conductive geotherm $T$, a range of $P-T$ conditions is calculated which can then be compared with the stability field of diamond and the mantle adiabat temperature as additional constraints. Calculating $T_{\mathrm{DH} 10}^{\mathrm{Al}-\mathrm{ol}}$ for all olivines from the Akwatia inclusion suite using a $40 \mathrm{~mW} / \mathrm{m}^{2}$ conductive geotherm of Hasterok and Chapman (2011) results in a $T$ range of $1005-1295{ }^{\circ} \mathrm{C}$ (ignoring one outlier of $930{ }^{\circ} \mathrm{C}$ ), whereas the $40 \mathrm{~mW} / \mathrm{m}^{2}$ geotherm intercepts the diamond-graphite transition intercepts at $1100{ }^{\circ} \mathrm{C}$ and $46 \mathrm{kbar}$. Thus, the $T_{\mathrm{DH} 10}^{\mathrm{Al}-\mathrm{l}}$ data is incompatible with a $40 \mathrm{~mW} / \mathrm{m}^{2}$ conductive geotherm, as it would imply that some olivine inclusions were trapped inside the graphite stability field. Using a $38 \mathrm{~mW} / \mathrm{m}^{2}$ conductive results in a range of $1042-1355^{\circ} \mathrm{C}$ (ignoring one outlier), whilst it intercepts the diamond-graphite transition at $950{ }^{\circ} \mathrm{C}$ and $44 \mathrm{kbar}$ and the mantle adiabat at $1370{ }^{\circ} \mathrm{C}$. Thus, $P-T$ estimates of all inclusions fall within the diamond stability field and below the mantle adiabat. A $39 \mathrm{~mW} / \mathrm{m}^{2}$ also results in an acceptable $P-T$ range, whereas using cooler conductive geotherms results in temperature estimates above the mantle adiabat. Thus, based on $T_{\mathrm{DH} 10}^{\mathrm{Al}}$ data alone, we can determine the paleogeotherm to be a $38-39 \mathrm{~mW} / \mathrm{m}^{2}$ conductive geotherm. This is the same result as obtained by traditional geothermobarometry.

\section{Discussion}

\section{Diamond paragenesis}

Peridotitic inclusions in diamonds can be subdivided into lherzolitic and harzburgitic parageneses (representing mantle source lithologies) based on the presence or absence of cpx, or Ca-saturation of garnet (Sobolev et al. 1973; Stachel and Harris 2008). Harzburgitic assemblages with strongly Ca-depleted garnets (G10 garnets; Dawson and Stephens 1975; Grütter et al. 2004) are of particular interest, as these are indicators for diamondiferous kimberlites (Gurney 1984; Gurney et al. 1993). However, many diamonds contain olivine inclusions only and no criteria exist to determine their paragenesis. Here we evaluate diamond paragenesis based on the trace element composition of its olivine inclusions.

\section{Ca-Al systematics}

A strong positive correlation exists between $\mathrm{Ca}$ and $\mathrm{Al}$ in grt-lherzolite mantle olivine due to the temperature dependence of concentrations of both elements in olivine and relatively constant $\mathrm{CaO}$ and $\mathrm{Al}_{2} \mathrm{O}_{3}$ activities in co-existing garnet and cpx (De Hoog et al. 2010). Indeed, lherzolitic olivines from Akwatia plot close to the mantle xenolith $\mathrm{Ca}-\mathrm{Al}$ array (De Hoog et al. 2010, Sobolev et al. 2009), with two exception of two inclusions, which plot towards the high $\mathrm{Ca} / \mathrm{Al}$ side.

In contrast to lherzolitic olivines, $\mathrm{Ca}$ and $\mathrm{Al}$ contents of harzburgitic and peridotitic (paragenesis undetermined) Akwatia olivines show significant scatter (Fig. 6a), most having low $\mathrm{Ca} / \mathrm{Al}$ values. This scatter could be caused by olivines equilibrating along different geothermal gradients and the difference in pressure dependence of $\mathrm{Ca}$ and $\mathrm{Al}$ partitioning (De Hoog et al. 2010; Köhler and Brey 1990). However, although the exact origin of the Akwatia suite of alluvial diamonds is unclear, they are likely of similar age and unlikely to reflect large temporal variations in geothermal gradients needed to significantly shift $\mathrm{Ca}-\mathrm{Al}$ trends (see $\mathrm{Ca}-\mathrm{Al}$ correlation for various conductive geotherms; Fig. 6a). More likely, Ca contents in olivine reflect low but variable $\mathrm{Ca}$ activity of the mantle environment, as indicated by $\mathrm{CaO}$ undersaturation of co-existing garnets (Stachel and Harris 1997b). A large fraction of low-Ca garnets was also 

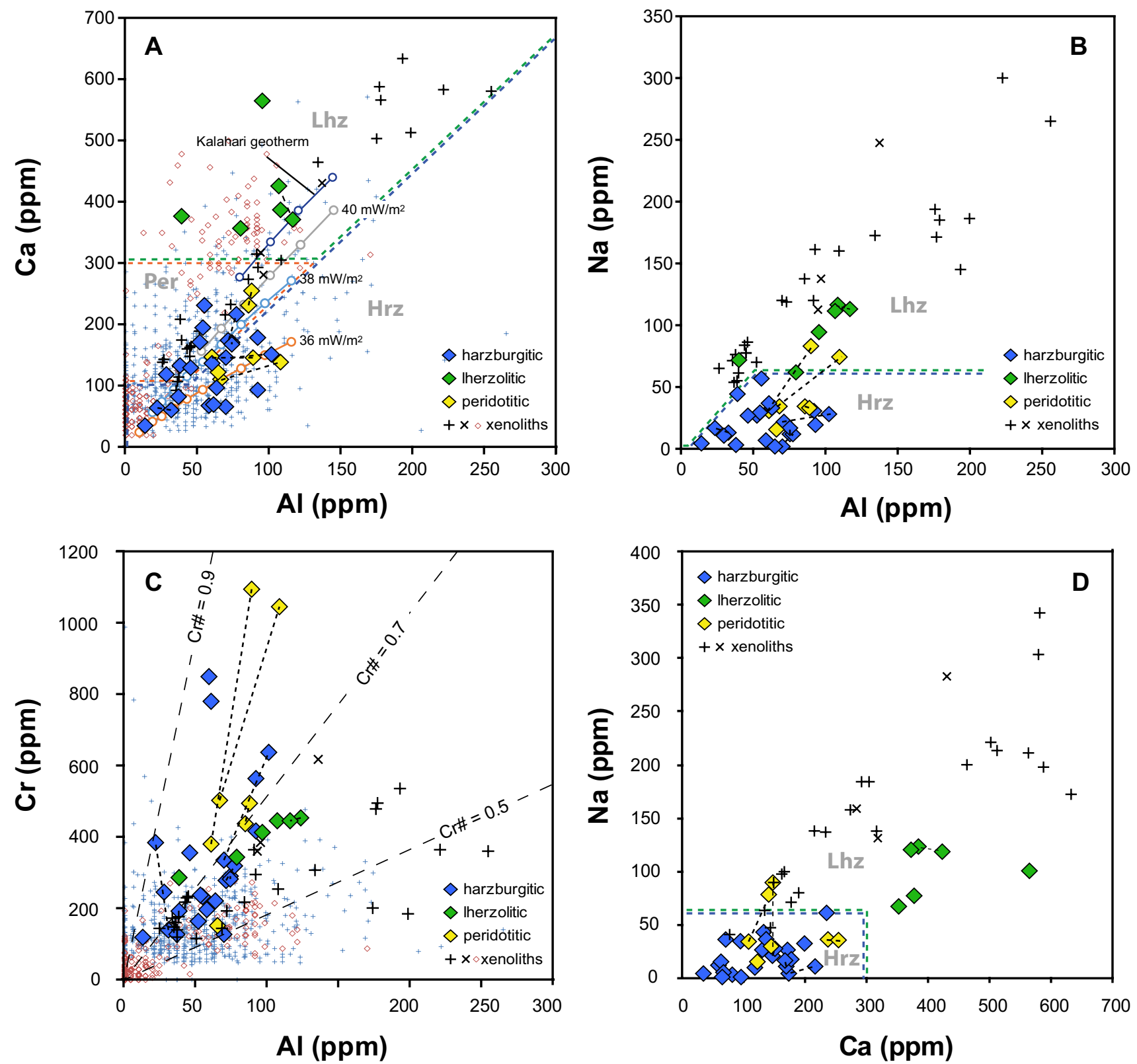

Fig. $6 \mathrm{Ca}$ vs. $\mathrm{Al}(\mathbf{a}), \mathrm{Na}$ vs. $\mathrm{Al}(\mathbf{b}), \mathrm{Cr}$ vs. $\mathrm{Al}(\mathbf{c})$ and $\mathrm{Ca}$ vs. $\mathrm{Na}(\mathbf{d})$ concentrations in olivine inclusions in Akwatia diamonds. Symbols connected with stippled lines indicate multiple analyses of the same olivine inclusion. Compositions of olivines from the literature are plotted for comparison (black plus and cross signs: grt lherzolite and harzburgite xenoliths with equilibration temperatures $>1050{ }^{\circ} \mathrm{C}$, respectively, De Hoog et al. 2010; small red diamonds and small blue plus signs: grt peridotite xenoliths and diamond-hosted inclusions, respectively, Sobolev et al. 2009). Further indicated in (a) is the predicted $\mathrm{Ca}-\mathrm{Al}$ trend in olivines equilibrated along various conductive

observed in the diamond inclusions dataset from Sobolev et al. (2009).

The different location of lherzolitic and harzburgitic olivines in $\mathrm{Al}-\mathrm{Ca}$ space allows olivine compositions to be used to determine host diamond paragenesis. All olivines

geotherms, including the Kalahari geotherm of Rudnick and Nyblade (1999) and 36, 38 and $40 \mathrm{~mW} / \mathrm{m}^{2}$ geotherms from Hasterok and Chapman (2011) calculated by inverting $T_{\mathrm{Al}-\mathrm{ol}}$ and $T_{\mathrm{Ca}-\mathrm{ol}}$ equations from De Hoog et al. (2010) with $\mathrm{Cr} \#_{\mathrm{ol}}=0.6$, with $50{ }^{\circ} \mathrm{C}$ temperature intervals (open circles) and the highest temperature indicated being $1350{ }^{\circ} \mathrm{C}$, the lowest temperature being where each geotherm intersects the graphite-diamond boundary. Fields indicated with dashed lines in (a), (b) and (d) indicate paragenesis of olivine inclusions in diamonds, with $\mathrm{Lhz}=$ lherzolitic paragenesis, $\mathrm{Hrz}=$ harzburgitic and Per $=$ peridotitic (undetermined paragenesis)

with $\mathrm{Ca} / \mathrm{Al}<2.2$ are of harzburgitic origin (Fig. 6a). In addition, since olivine in equilibrium with clinopyroxene has at least $100 \mu \mathrm{g} / \mathrm{g} \mathrm{Ca}$ in the $P-T$ range where diamond is stable ( $>1050{ }^{\circ} \mathrm{C}$; Fig. $6 \mathrm{a}$ ), olivines with $<100 \mu \mathrm{g} / \mathrm{g}$ Ca must also be harzburgitic, even if they fall on the mantle olivine Al-Ca 
array. Note that this applies to olivine inclusions in diamonds only, as low- $T$ lherzolite xenoliths also have $\mathrm{Ca}<100 \mu \mathrm{g} / \mathrm{g}$, but these were sourced from the graphite stability field (De Hoog et al. 2010). All olivines with $>300 \mu \mathrm{g} / \mathrm{g} \mathrm{Ca}$ and $\mathrm{Ca} /$ $\mathrm{Al} \geq 2.2$ are of lherzolitic paragenesis. For olivines that fall on or near the mantle array and have 100-300 $\mu \mathrm{g} / \mathrm{g} \mathrm{Ca}$, their paragenesis is uncertain (i.e., peridotitic). Following these rules, 12 out of 19 harzburgitic olivine inclusions are correctly classified as such, whereas seven cannot be classified. Of the four peridotitic olivine inclusions (paragenesis undetermined), two are harzburgitic according this classification. All five lherzolitic inclusions are identified correctly.

As the distinction is based on generally applicable traceelement partitioning data, these rules can also be applied to other diamond-hosted inclusions suites. When applied to the diamond-hosted inclusion suites from Sobolev et al. (2009), the majority of olivines from Yakutia mines (299 out of 505, or $59 \%$ ) are harzburgitic, whereas only 20 are lherzolitic (4\%), the remainder being of unidentified origin (peridotitic). In contrast, olivines from the Majhgawan mine, India, and from Argyle, Australia, as well as the majority of inclusions from Snap Lake, Canada, cannot be classified (i.e., are peridotitic). As no $\mathrm{Na}$ data were reported, further refinement using the scheme below based on $\mathrm{Na}-\mathrm{Ca}$ and $\mathrm{Na}-\mathrm{Al}$ systematics is unfortunately not possible for the Sobolev et al. (2009) dataset.

\section{Na-Al-Ca systematics}

Although many olivine inclusions can be successfully classified using $\mathrm{Ca}-\mathrm{Al}$ systematics, a significant proportion of harzburgitic inclusions could not be classified due to overlap of harzburgitic and lherzolitic inclusions (peridotite field in Fig. 6a). As harzburgites are depleted in $\mathrm{Na}$ as well as $\mathrm{Ca}$, $\mathrm{Na}-\mathrm{Al}-\mathrm{Ca}$ systematics may be used to provide additional constraints on mantle paragenesis. Sodium shows welldefined trends with $\mathrm{Al}$ and $\mathrm{Ca}$ in olivines from lherzolitic mantle xenoliths, as $\mathrm{Na}$ activity is buffered by co-existing clinopyroxene and therefore, like for $\mathrm{Ca}$ and $\mathrm{Al}$, temperature is the main control on Na contents of olivine (De Hoog et al. 2010). In contrast, Akwatia olivines have very low $\mathrm{Na}$ contents relative to $\mathrm{Al}$ (Fig. 6b) and $\mathrm{Ca}$ (Fig. 6d). Even most lherzolitic olivine inclusions fall below the xenolith-based $\mathrm{Al}-\mathrm{Na}$ and $\mathrm{Ca}-\mathrm{Na}$ arrays of grt-lherzolites (De Hoog et al. 2010). Akwatia clinopyroxene inclusions have low jadeite contents (1-3\%) compared to clinopyroxene from mantle xenoliths (4-14\%; De Hoog et al. 2010) and clinopyroxene in diamonds elsewhere ( $7 \pm 4 \%$; Stachel and Harris 2008), which probably causes the relatively low Na contents of lherzolitic olivine inclusions from Akwatia. Harzburgitic olivine inclusions have even lower $\mathrm{Na}$ contents. Therefore, $\mathrm{Na}-\mathrm{Al}$ systematics allow us to distinguish between harzburgitic and lherzolitic olivines: olivines with $\mathrm{Na}>60 \mu \mathrm{g} / \mathrm{g}$ or $\mathrm{Na} /$
$\mathrm{Al}>0.75$ are lherzolitic, whereas olivines with $\mathrm{Na} \leq 60 \mu \mathrm{g} / \mathrm{g}$ and $\mathrm{Na} / \mathrm{Al} \leq 0.75$ are harzburgitic (Fig. 6b). Following these rules, all 19 harzburgitic inclusions are correctly classified as such, and so are all five lherzolitic inclusions. Of the four peridotitic olivine inclusions (paragenesis undetermined), three are classified as harzburgitic, whereas the remaining one is uncertain due to heterogeneity in its $\mathrm{Al}$ and $\mathrm{Na}$ contents. $\mathrm{Na}-\mathrm{Ca}$ systematics show similar patterns, so olivine inclusions with $<60 \mu \mathrm{g} / \mathrm{g} \mathrm{Na}$ and $<300 \mu \mathrm{g} / \mathrm{g} \mathrm{Ca}$ are harzburgitic (Fig. 6d).

Combining the $\mathrm{Ca}-\mathrm{Al}, \mathrm{Na}-\mathrm{Ca}$ and $\mathrm{Na}-\mathrm{Al}$ classifications, all harzburgitic and lherzolitic inclusions are classified successfully, and all peridotitic (unspecified) inclusions were classified as harzburgitic. Harzburgitic olivines dominate the Akwatia suite, which matches the distribution of the Akwatia garnet inclusions, as well as the distribution of diamondhosted inclusions suites worldwide (Gurney 1984; Stachel and Harris 2008).

\section{Implications for olivine as a diamond indicator mineral}

Olivine can potentially be used as a diamond indicator mineral. Previous use of olivine in diamond exploration has mainly focussed on identifying olivine from kimberlite, i.e., as a kimberlite indicator mineral (e.g., Matveev and Stachel 2007; Shchukina and Shchukin 2018), but this provides little indication of diamond potential. Diamond formation is associated with garnet-bearing sections of the SCLM in which harzburgites predominate over lherzolites (Gurney et al. 1993). Olivines with a harzburgitic paragenesis, following the identification scheme presented earlier, are derived from the same source as G10 garnets. However, since we only compared the olivine inclusions to olivines from garnet peridotite xenoliths with equilibrium temperatures $>1050{ }^{\circ} \mathrm{C}$, it is possible that olivines from lower temperature xenoliths, or from other lithologies, have $\mathrm{Al}-\mathrm{Ca}-\mathrm{Na}$ systematics that would identify them as harzburgitic, whereas in fact they could be derived from, e.g., low- $T$ lherzolites. Indeed, we note that a few lherzolitic mantle xenoliths plot inside the fields we have identified as harzburgitic (Fig. 6). These are xenoliths that have equilibrium temperatures just over $1050{ }^{\circ} \mathrm{C}$, and thus are very close to the graphite-diamond transition. In addition, olivines from low- $T$ lherzolite xenoliths would overlap with our harzburgite field as well (De Hoog et al. 2010). Thus, more stringent filtering needs to be applied to be certain that an olivine of unknown origin is derived from the same source as G10 garnets.

We recommend that the dataset is first filtered to olivines of mantle origin $(\mathrm{Fo}=92-95 \%$ and $\mathrm{NiO}>0.3 \mathrm{wt} \%$; Fig. 2) with $\mathrm{Al}>40 \mu \mathrm{g} / \mathrm{g}, \mathrm{Ca}<300 \mu \mathrm{g} / \mathrm{g}$ and $\mathrm{Na}<60 \mu \mathrm{g} / \mathrm{g}$. This removes most lherzolites and low- $T$ peridotites, as well as olivines of non-mantle origin. Then 'G10' olivines are those from the filtered dataset that have at least two of the 


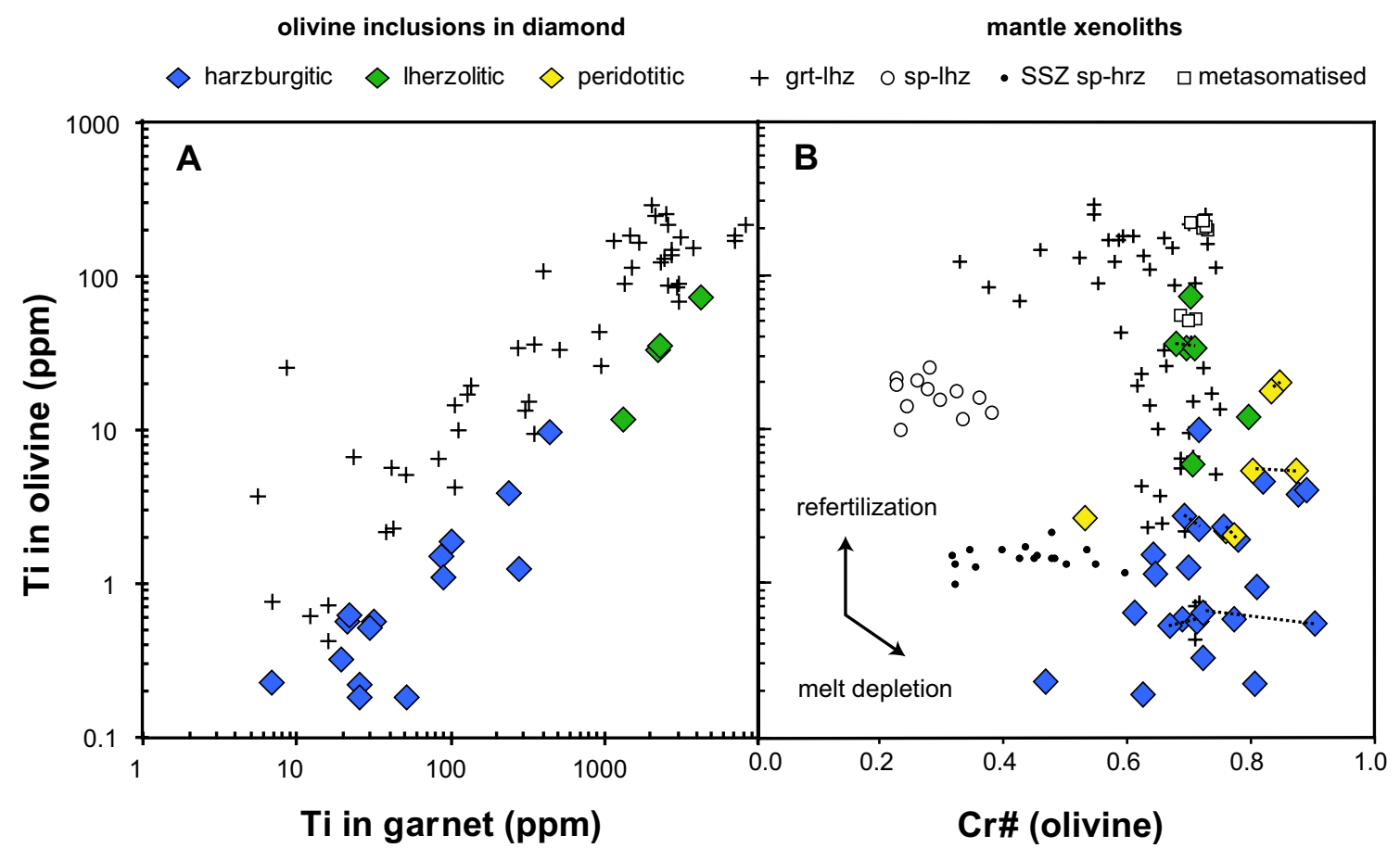

Fig. 7 Co-variation of $\mathrm{Ti}$ in olivine vs. Ti in garnet (a) and $\mathrm{Ti}$ in olivine vs. Cr\# of olivine (b) for inclusions in Akwatia diamonds. Compositions of olivine in grt and grt-spinel peridotite xenoliths from De Hoog et al. (2010) are indicated for comparison, as well as (in b)

following three ratios: $\mathrm{Ca} / \mathrm{Al}<2.2, \mathrm{Al} / \mathrm{Na}>1.5$ and $\mathrm{Ca} /$ $\mathrm{Na}<5$. This results in a proportion of harzburgitic inclusions not being identified as such, but no olivines from mantle xenoliths are incorrectly identified as harzburgitic. Applying this scheme to the 28 Akwatia olivine inclusions results in 11 'G10' olivines, whereas none of the olivines from De Hoog et al. (2010), including garnet and spinel peridotites, kimberlites and picrites, were classified as 'G10' olivines.

If $\mathrm{Na}$ has not been measured, as is the case for much of the literature, including the high-precision EPMA technique employed by several groups (Batanova et al. 2015; Sobolev et al. 2008), the filtering can be simplified to $\mathrm{Al}>40 \mu \mathrm{g} / \mathrm{g}, \mathrm{Ca}<300 \mu \mathrm{g} / \mathrm{g}$ and $\mathrm{Ca} / \mathrm{Al}<2.2$. This results in less olivines identified positively as ' $\mathrm{G} 10$ ' olivines. As an example, when applied to the diamond-hosted inclusion suites from Sobolev et al. (2009), for Yakutian kimberlites just over one-third of olivine inclusions is classified as 'G10'. This proportion drops considerably for the other localities (diamonds from elsewhere in Russia, as well as Canada), and to none at all for diamond-hosted olivine inclusions from India and Australia. Unfortunately, due to Na missing from the Sobolev et al. (2009) dataset, it is impossible to determine if the latter suites are lherzolitic or harzburgitic. Of all peridotite xenoliths from the same Yakutia, only one contains 'G10' olivine. Therefore, the usefulness of this olivine classification scheme as a supra-subduction zone (SSZ) spinel harzburgites from Kamchatka (Ionov 2010) and metasomatised mantle xenoliths (dunites, wehrlites and websterites) from the Kimberley kimberlite (Rehfeldt et al. 2008)

diamond indicator mineral needs further evaluation, but including $\mathrm{Na}$ in analytical setups would be beneficial as it is more useful to constrain diamond paragenesis than $\mathrm{Ca}$.

\section{Formation conditions of diamond mantle source}

\section{Melt depletion and refertilisation}

The Ti content of olivine serves as a proxy for bulk rock $\mathrm{TiO}_{2}$ content (De Hoog et al. 2010; Hermann et al. 2005), which is an important indicator of melt depletion and refertilisation of mantle rocks (e.g., Bizimis et al. 2000, Rehfeldt et al. 2008). Low Ti contents of Akwatia olivines, particularly the harzburgitic inclusions, indicate that their mantle source was highly depleted in fusible elements. Titanium contents in olivine correlate well with $\mathrm{TiO}_{2}$ contents of coexisting garnet (Fig. 7a), although they are offset from the mantle xenolith array (discussed below). The low Ti contents of the garnets were taken as evidence by Stachel and Harris (1997a) that the Akwatia diamond source rocks avoided refertilisation through a melt. The olivine data support this view. About half the harzburgitic olivines have $<1 \mu \mathrm{g} / \mathrm{g}$ $\mathrm{Ti}$, which equates to $<4 \mu \mathrm{g} / \mathrm{g}$ in the bulk rock (De Hoog et al. 2010), and the lowest values are $0.2 \mu \mathrm{g} / \mathrm{g}$ Ti. These Ti contents are lower even than those in olivine from highly depleted supra-subduction zone peridotites $(0.8-2 \mu \mathrm{g} / \mathrm{g}$; 
Ionov 2010; Tollan et al. 2017) and indicate extremely high degrees of melting in excess of $30 \%$. Similarly low Ti contents were reported for olivine in grt-spinel lherzolites from Kaalvallei, Kaapvaal Craton (De Hoog et al. 2010). In contrast, Ti contents of lherzolitic olivine inclusions are similar to those of olivine from grt-lherzolite xenoliths, indicating that either their source rocks did not experience extensive melt depletion or that they were refertilised by Ti-bearing melts before entrapment of the inclusions into their host diamonds.

One peculiar feature of the Akwatia dataset is that $\mathrm{Ti}$ in olivine vs. garnet appears to be offset relative to the mantle xenolith data (Fig. 7A), i.e., Ti in olivine is about four times lower than expected based on $\mathrm{Ti}$ in co-existing garnet. This is true for lherzolitic as well as harzburgitic olivine. This offset is difficult to explain as one would expect $D_{\mathrm{Ti}}^{\mathrm{g} t / \mathrm{l}}$ to be relatively constant, with only a small dependence on temperature and garnet composition. A change in Ti substitution from the octahedral to the tetrahedral site was reported in wet versus dry mantle olivine, and the presence of $\mathrm{Na}$ appears to enhance uptake of $\mathrm{Ti}$ in olivine (Tollan et al. 2018). As Na contents in Akwatia olivines inclusions are relatively low, we cannot exclude a crystal-chemical control on Ti partitioning. Nevertheless, the broad correlation with of $\mathrm{Ti}$ in Akwatia olivine inclusion with $\mathrm{TiO}_{2}$ in co-existing garnet does indicate that $\mathrm{Ti}$ in olivine does follow a similar pattern as the mantle xenolith database and reflects that of the bulk rock (De Hoog et al. 2010).

To investigate whether lherzolitic olivines were refertilised by melt infiltration or instead escaped melt depletion altogether, we compared olivine $\mathrm{TiO}_{2}$ contents with their $\mathrm{Cr}$ (Fig. 7b). Cr\# of olivine serves as an indicator of melt depletion is, as it correlates with Cr\# of co-existing chromite (De Hoog et al. 2010), which increases with increasing degrees of melt extraction (e.g., Dick and Bullen 1984; Hellebrand et al. 2001). This is also illustrated by comparing $\mathrm{Ti}$ and $\mathrm{Cr} \#$ of fertile spinel lherzolites with residual supra-subduction zone harzburgites (Fig. 7b). It is thought that most garnet peridotites from the subcontinental lithosphere underwent low-pressure melting in the spinel stability field (Brey and Shu 2018; Stachel et al. 1998) and would, therefore, show a similar $\mathrm{Cr} \#-\mathrm{TiO}_{2}$ trend. Cooling after melting would not change $\mathrm{Cr} \#$ of olivine much, as $\mathrm{Al}$ and $\mathrm{Cr}$ have similar temperature and pressure dependence (De Hoog et al. 2010). Most Akwatia olivines, including lherzolitic inclusions, have $\mathrm{Cr} \#$ of $0.6-0.7$ with some higher $\mathrm{Cr} \#$ values up to 0.9 (Fig. 6c). This suggests that the mantle source of the olivines had very high $\mathrm{Cr} \#$, consistent with the high $\mathrm{Cr}_{2} \mathrm{O}_{3}$ contents of garnet inclusions in the Akwatia diamonds (Stachel and Harris 1997a). No Cr\# values lower than 0.45 are present, in contrast to the diamond-hosted inclusion suites from Sobolev et al. (2009), in which over a quarter of inclusions has $\mathrm{Cr} \#<0.45$. This is again consistent with the mantle source of Akwatia diamonds having high $\mathrm{Cr} \#$, and a very high degree of melt depletion. Importantly, lherzolitic inclusions have similar $\mathrm{Cr} \#$ as harzburgitic inclusions (Fig. 7b), which suggests these also experienced large degrees of melt depletion, which is at odds with their high $\mathrm{TiO}_{2}$ contents. This indicates that lherzolitic olivine was affected by small degrees of metasomatism by Ti-bearing melts prior to entrapment in the diamond, which would increase Ti contents of the strongly depleted mantle, including olivine, but would not affect Cr\# significantly (De Hoog et al. 2010; Rehfeldt et al. 2008). Harzburgitic Akwatia olivine inclusions escaped refertilisation (as indicated by their low $\mathrm{Ti}$ and high Cr\#, Fig. 7b), presumably due to isolation from the surrounding mantle by the diamond host, and consequently were encapsulated into their host diamonds prior to any major refertilisation.

A similar pattern of $\mathrm{TiO}_{2}$ vs. $\mathrm{Cr} \#$ can be seen for Akwatia garnet inclusions, but $\mathrm{Cr} \#$ tend to be lower for lherzolitic garnets than harzburgitic ones, and would therefore also be consistent with a partial melting trend for lherzolitic garnets. This difference in behaviour between olivine and garnet is likely due to the poor correlation between $\mathrm{Cr} \#$ of olivine and garnet inclusions from the same diamond. This is a common feature also noted in mantle xenoliths (De Hoog et al. 2010), where a much better correlation between the $\mathrm{Cr} \#$ of olivine and cpx was observed than with garnet. This is probably due to the pressure dependence of $\mathrm{Cr} \#$ in garnet in equilibrium with Cr-spinel (Grütter et al. 2006) and the fact that the $\mathrm{Cr} \#$ of spinel in equilibrium with garnet increases further with depth until spinel becomes exhausted (Klemme 2004). Confirmation that lherzolitic inclusions probably record melt refertilisation comes from cpx inclusions in the Akwatia diamonds. These have Cr\# from 27 up to $41 \%$, which is considerably higher than cpx from strongly depleted suprasubduction zone harzburgitic xenoliths (Ionov 2010), which have Cr\# ranging from 16 to $25 \%$. Therefore, the high Cr\# of Akwatia cpx is due to their formation during melt infiltration with the Cr\# of cpx being imposed by the composition of the ambient mantle.

\section{Trivalent cation behaviour and mantle oxidation state}

Vanadium and $\mathrm{Cr}$ can occur in several oxidation states and may, therefore, provide information on the redox condition of their environment (e.g., Papike et al. 2005). Vanadium and $\mathrm{Cr}$ in Akwatia olivine inclusions (Fig. 8a) are rather scattered instead of the excellent correlation observed in olivines from mantle xenoliths (De Hoog et al. 2010; Ionov 2010; Witt-Eickschen and O'Neill 2005), showing high and variable $\mathrm{Cr} / \mathrm{V}$ values instead. Akwatia harzburgitic garnets also exhibit high $\mathrm{Cr} / \mathrm{V}$ compared to garnets from mantle 

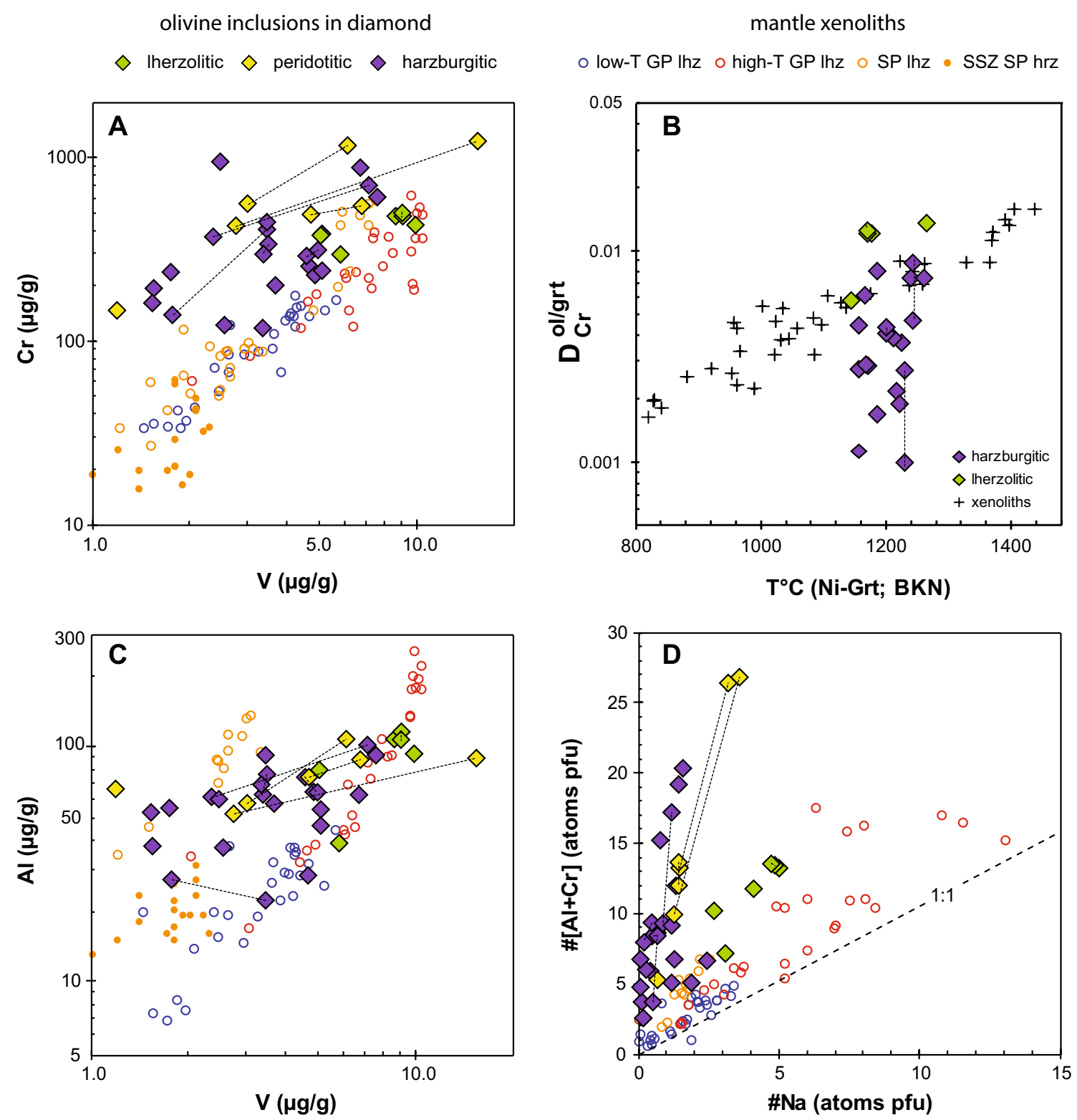

Fig. 8 Plots of a Cr vs. V, b $D_{\mathrm{Cr}}^{\mathrm{ol} / \mathrm{grt}}$ vs. $T_{\mathrm{Canil}}^{\mathrm{Ni}-\text { grt }}\left({ }^{\circ} \mathrm{C}\right)$, $\mathbf{c} \mathrm{Al}$ vs. V, and d $\# \mathrm{Na}$ vs. \#[Al $+\mathrm{Cr}]$ in olivines from Akwatia diamonds compared to olivine from mantle xenoliths including garnet peridotites, separated in high- and low- $T$ peridotites (boundary $=1050^{\circ} \mathrm{C}$ ) (De Hoog et al.

xenoliths, in which both elements have a narrow compositional range in their major hosts cpx and garnet, and their concentrations in olivine are largely controlled by equilibration temperature of the xenoliths (De Hoog et al. 2010). Based on their equilibration temperatures, Akwatia olivine inclusions are expected to have $>5 \mu \mathrm{g} / \mathrm{g} \mathrm{V}$ and $>150 \mu \mathrm{g} / \mathrm{g}$ $\mathrm{Cr}$, but nearly all harzburgitic olivine inclusions have lower $\mathrm{V}$. Chromium in olivine is also lower than expected when considering the high $\mathrm{Cr} \#$ of co-existing garnets.

One possible explanation for the offset of Akwatia inclusions from the mantle array is that $\mathrm{Cr}$ and $\mathrm{V}$ contents

2010), spinel lherzolites (De Hoog et al. 2010; Witt-Eickschen and O'Neill 2005) and supra-subduction zone spinel harzburgites (Ionov 2010). For the mantle xenoliths (b) no $T_{\mathrm{Canil}}^{\mathrm{Ni}-\mathrm{grt}}$ was available, so $T_{\mathrm{BKN}}^{\mathrm{cpx}-\mathrm{opx}}$ was used instead

are controlled by $f \mathrm{O}_{2}$. Under typical oxidation conditions in the upper mantle (IW to NNO buffers; Berry et al. 2003) most $\mathrm{V}$ will occur as $\mathrm{V}^{3+}$ or $\mathrm{V}^{4+}$ and $\mathrm{Cr}$ as $\mathrm{Cr}^{3+}$ (Canil 2002; Papike et al. 2005). $\mathrm{V}^{4+}$ has an ionic radius close to $\mathrm{Ti}^{4+}$, which has very low compatibility in olivine. $\mathrm{V}^{2+}$ would probably be highly compatible in olivine, having an ionic radius very close to $\mathrm{Fe}^{2+}$, but occurs only at very low oxidation states (below the IW buffer). $\mathrm{Cr}^{2+}$ has a similar ionic radius and charge to $\mathrm{Fe}^{2+}$ and $\mathrm{Mn}^{2+}$, and therefore expected to be more compatible in olivine than $\mathrm{Cr}^{3+}$. Indeed, in peridotite melting experiments, olivine-melt 
partition coefficients for $\mathrm{Cr}^{2+}$ and $\mathrm{Cr}^{3+}$ are comparable, but $D_{\mathrm{Cr}}^{\mathrm{o} / / \text { px }}$ and $D_{\mathrm{Cr}}^{\mathrm{o} / \mathrm{cpx}}$ increase strongly with lower oxygen fugacity (e.g., Mallmann and O'Neill 2009). A similar increase in compatibility of $\mathrm{Cr}^{2+}$ in olivine at low oxidation fugacity was observed in Cr-spinel bearing lithologies (Li et al. 1995).

Based on the crystal-chemically induced relationship between oxygen fugacity and pressure, in average lithospheric mantle $f \mathrm{O}_{2}$ decreases from about $\Delta \mathrm{QMF}=-1$ to -2.9 between 100- and 200-km depth (Canil et al. 1994), i.e., remains well above the IW buffer and the stability field of $\mathrm{V}^{2+}$ (Canil et al. 1994; Luth and Stachel 2014; Stagno et al. 2013). $f \mathrm{O}_{2}$ estimates based on $\mathrm{Cr}$-spinel-olivine pairs in Akwatia diamonds (Cr-spinel compositions from Stachel and Harris 1997b) using the Ballhaus et al. (1991) calibration (with 1994 correction; Ballhaus et al. 1994) average to $\Delta \mathrm{QMF}=-1.6 \pm 1.3$. This is close to the EMOD buffer (enstatite + magnesite $=$ olivine + diamond $)$, and probably an overestimate of oxygen fugacity due to inaccuracies of the Ballhaus et al. (1991) calibration at high pressures. Nevertheless, even at this relatively high oxidation state, some $\mathrm{Cr}^{2+}$ would likely be present in Akwatia olivines due to the high temperatures of equilibration and high $\mathrm{MgCr}_{2} \mathrm{O}_{4}$ contents of syngenetic chromite (Berry et al. 2003; Li et al. 1995; Stachel and Harris 1997b). Three Akwatia diamonds with olivine as well as $\mathrm{Cr}$-spinel inclusions can be used to estimate the $\mathrm{Cr}^{2+}$ content following $\mathrm{Li}$ et al. (1995). Using average $T_{\mathrm{DH} 10}^{\mathrm{Al}-\mathrm{Cl}}$ of $1140^{\circ} \mathrm{C}$ and $\Delta \mathrm{QMF}=-2$, ca. $80-130 \mu \mathrm{g} / \mathrm{g}$ $\mathrm{Cr}^{2+}$ is divalent out of $117-327 \mu \mathrm{g} / \mathrm{g}$ total $\mathrm{Cr}$ present in these olivine inclusions. These estimates suggest that a significant fraction of $\mathrm{Cr}^{2+}$ is present in most Akwatia olivines, which is in agreement with spectroscopy measurements of $\mathrm{Cr}$ oxidation state in olivine inclusions from South African diamonds (Sutton et al. 1993), in which one-third of total Cr was present as divalent $\mathrm{Cr}$. This $\mathrm{Cr}^{2+}$ would add to total $\mathrm{Cr}$ in olivine, as it is incorporated following a exchange reaction different to $\mathrm{Cr}^{3+}$. Indeed, some Akwatia olivines have very high $\mathrm{Cr}$ contents (up to $1090 \mu \mathrm{g} / \mathrm{g} \mathrm{Cr}$ or $0.16 \mathrm{wt} \% \mathrm{Cr}_{2} \mathrm{O}_{3}$ ). High $\mathrm{Cr}$ contents have also been observed in olivine inclusions from other diamond suites (Hervig et al. 1980b; Sobolev et al. 2009). More reducing conditions are required to get higher $\mathrm{Cr}$ contents, and must be around QMF-3 to reach 0.16 wt\% observed in some Akwatia olivine inclusions, which is still within the range of oxidation states in cratonic mantle (Luth and Stachel 2014). We note, however, that the Li et al. (1995) calibration is only valid for olivine in equilibrium with Cr-spinel. Many olivines probably had no Cr-spinel in their assemblage when they were trapped in the diamond, as the $39 \mathrm{~mW} / \mathrm{m}^{2}$ conductive geotherm intersects the $\mathrm{Cr}$-spinel out boundary at about $1150{ }^{\circ} \mathrm{C}$ and $52 \mathrm{kbar}$ (Klemme et al. 2009), whereas most olivine inclusions were derived from higher $P-T$ conditions. Thus, the amount of divalent $\mathrm{Cr}$ in olivine from $\mathrm{Cr}$-spinel-free assemblages remains uncertain.
In addition, despite the high $\mathrm{Cr}$ contents of some Akwatia olivines, most olivines have in fact relatively low $\mathrm{Cr}$ contents considering their equilibration temperature and high $\mathrm{Cr} \#$ in co-existing garnet. This is demonstrated in Fig. 8b., where $D_{\mathrm{Cr}}^{\mathrm{ol} / \mathrm{rt}}$ ranges from 0.001 to 0.009 for harzburgitic olivine inclusions in Akwatia diamonds, compared to 0.005-0.016 for olivine from the mantle xenolith database equilibrated at similar temperatures. A similar pattern of low $D^{\text {ol/grt }}$ values can be observed for $\mathrm{V}$ and Sc (not shown), but not for $\mathrm{Al}$ (Fig. 5b). As Sc is not affected by oxidation state but otherwise has a similar geochemical behaviour as $\mathrm{Cr}$ and $\mathrm{V}$, any redox-sensitive processes should be clearly visible in changes in $\mathrm{Cr} / \mathrm{Sc}$ and/or V/Sc (Canil 1999b, 2002). No such difference is observed for $\mathrm{V}$, and only a small difference for $\mathrm{Cr} / \mathrm{Sc}$, probably related to the presence of divalent $\mathrm{Cr}$, as discussed above.

Thus, $\mathrm{Cr}$, Sc and $\mathrm{V}$ all have low $D^{\mathrm{Ol} / \text { grt }}$ values for harzburgitic olivines, whereas lherzolitic inclusions are similar or higher than olivines from mantle xenoliths (Fig. 8b). We interpret the difference between harzburgitic and lherzolitic inclusions as a change in exchange mechanisms for trivalent cations due to the exhaustion of clinopyroxene. Trivalent cations in olivine need to be charge balanced, e.g., by monovalent ions or vacancies on the $\mathrm{M}$ site (where $\mathrm{Mg}$ and Fe reside) or by trivalent ions on the Si site (De Hoog et al. 2010; Kurosawa et al. 1997; Witt-Eickschen and O'Neill 2005). A strong correlation between \#Na (nr. of atoms per functional unit) and \#[Al+Cr] close to $1: 1$ was observed for lherzolitic mantle olivine, suggesting that Na plays an important role in the charge balance of trivalent cations in garnet lherzolites (De Hoog et al. 2010). In harzburgites, where cpx has been exhausted during partial melting, $\mathrm{Na}$ activity in the residue has decreased strongly. Indeed, for Akwatia olivines, \#Na is strongly depleted relative to $\#[\mathrm{Cr}+\mathrm{Al}]$, indicating that other substitution mechanisms must be active in Na-undersaturated olivine (Fig. 8d).

The difference in substitution mechanisms is further illustrated in Fig. 8a, c and d. Chromium and V behave similarly in garnet peridotite and spinel peridotite xenoliths. Lherzolitic olivine inclusions fall on that trend (Fig. 8a), or slightly above, which can be explained by the presence of $\mathrm{Cr}^{2+}$. However, all other olivine inclusions are strongly depleted in $\mathrm{V}$ compared to mantle xenoliths equilibrated under similar $P-T$ conditions (high- $T$ GP lherzolites in Fig. 8a). Low V contents are difficult to explain with a change in oxidation state, as $\mathrm{V}^{2+}$ would, like $\mathrm{Cr}^{2+}$, become more compatible in olivine relative to co-existing pyroxene and spinel (Li et al. 1995; Mallmann and O'Neill 2009), and requires oxygen fugacities below the IW buffer, which are unlikely to occur in cratonic mantle (Luth and Stachel 2014). Therefore, we conclude that the lack of Na for charge balance reduces the amount of $\mathrm{V}$ in harzburgitic olivine. Figure $8 \mathrm{~d}$ shows that $\# \mathrm{Na}$ is significantly lower than the amount 
required to charge balance trivalent cations (expressed as $\#[\mathrm{Al}+\mathrm{Cr}]$, note that for simplicity of the discussion we have ignored $\mathrm{Li}, \mathrm{Sc}$ and $\mathrm{V}$ in this figure, as their contribution is insignificant relative to $\mathrm{Na}, \mathrm{Al}$ and $\mathrm{Cr}$ ), and therefore other substitution mechanisms than $\mathrm{Na}-\mathrm{M}^{3+}$ must play a role.

It is worth noting that of the trivalent cations, $\mathrm{Al}$ partitioning into olivine appears to be least affected by the absence of cpx, which is important for its use as a singleelement thermometer $\left(T_{\mathrm{DH} 10}^{\mathrm{Al}-\mathrm{l}}\right)$. Its concentrations are similar in harzburgitic and lherzolitic inclusions, as well as olivines from mantle xenoliths (Fig. 8c). It is also relatively unaffected by the presence of spinel, which has a strong effect on the distribution of $\mathrm{Cr}$ and $\mathrm{V}$ (Fig. 8a, c). Whilst in garnet peridotites the $\mathrm{Na}-\mathrm{Al}$ exchange mechanism appears to be dominant (De Hoog et al. 2010), in spinel peridotites a Tschermak-style substitution of $\mathrm{Al}$ occurs, i.e., $\mathrm{Al}$ on the $\mathrm{M}$ site is not charge balanced by $\mathrm{Na}$, but by another $\mathrm{Al}$ replacing Si (De Hoog et al. 2010; Witt-Eickschen and O'Neill 2005). It appears that Tschermak substitution becomes important in garnet harzburgites if little $\mathrm{Na}$ to charge-balance $\mathrm{Al}$ is present.

\section{Chromium heterogeneity: syn-eruptive hydrogen loss?}

A complicating factor to the interpretation of $\mathrm{V}$ and $\mathrm{Cr}$ contents of Akwatia olivines is the large within-grain variability observed for both elements, whereas most other trace elements show no such variability (Fig. 3). Complex oscillatory zoning patterns of $\mathrm{P}, \mathrm{Cr}$ and $\mathrm{Al}$ have been recorded in olivines from basaltic lavas and spinel peridotite xenoliths (Mallmann et al. 2009; Milman-Barris et al. 2008), whereas other elements showed no such zoning (note that $\mathrm{V}$ was not measured in these studies). This indicates slow diffusion of $\mathrm{Cr}$ and $\mathrm{Al}$ in olivine relative to $\mathrm{Ca}, \mathrm{Mn}$ and $\mathrm{Ni}$ and thus points to $\mathrm{Cr}-\mathrm{Al}$ zoning in Akwatia olivine inclusions being a primary growth feature. However, Akwatia olivines do not show oscillatory zoning, as element mapping shows that $\mathrm{Cr}$ is seemingly randomly distributed (Electronic Supplement Fig. S4). In addition, growth zoning is at odds with a likely mantle residence of $>1 \mathrm{Ga}$ for these diamonds (assuming Early Archean formation of harzburgitic diamonds and exhumation at about 2.2 Ga; Gurney et al. 2010; Stachel and Harris 1997b), as it is inconceivable that such zoning patterns are preserved in olivine at mantle conditions $\left(T>1000{ }^{\circ} \mathrm{C}\right)$ for billions of years. Therefore, the $\mathrm{Cr}$ and $\mathrm{V}$ variability must be a relatively recent feature.

One possible explanation is related to the loss of hydrogen from olivine inclusions during diamond ascent in kimberlitic magma. Although the unresorbed shapes of Akwatia diamonds indicate that residence time in the magma was short, it has been suggested that the source of these diamonds were komatiites (Canales and Norman 2003), which have slower magma ascent rates than kimberlites (e.g., Russell et al. 2012). The following reaction was proposed by Ingrin and Skogby (2000) to explain possible hydrogen loss from mantle minerals during ascent to the surface:

$\mathrm{Fe}^{2+}+\mathrm{OH}^{-}=\mathrm{Fe}^{3+}+\mathrm{O}^{2-}+1 / 2 \mathrm{H}_{2}$

but if $\mathrm{Cr}^{2+}$ is present, this reaction would be preceded by:

$\mathrm{Cr}^{2+}+\mathrm{OH}^{-}=\mathrm{Cr}^{3+}+\mathrm{O}^{2-}+1 / 2 \mathrm{H}_{2}$

as $\mathrm{Cr}^{2+}$ oxidises at lower oxygen fugacity than $\mathrm{Fe}^{2+}$ (Schreiber et al. 1987). As hydrogen diffuses very fast in olivine and, therefore, readily escapes into the boundary layer between olivine and diamond, this process results in oxidation of the olivine inclusion. The presence of methane $\left(\mathrm{CH}_{4}\right)$, detected in thin fluid layers around silicate inclusions in diamonds, has been interpreted as the result of $\mathrm{H}_{2}$ escaping from the inclusions and reacting with the diamond host to form $\mathrm{CH}_{4}$ (Smith et al. 2018). It also explains the observation that no hydroxyl has been detected in diamond-hosted olivine inclusions (Matsyuk and Langer 2004), whereas the maximum solubility of $\mathrm{H}_{2} \mathrm{O}$ in olivine equilibrated at 5-6 GPa is ca. 150-200 ppm (Demouchy and Bolfan-Casanova 2016). This amount of $\mathrm{H}_{2} \mathrm{O}$ is enough (on a $1: 1$ atomic equivalent) to oxidise $870-1160 \mu \mathrm{g} / \mathrm{g} \mathrm{Cr}^{2+}$, which is higher than $\mathrm{Cr}^{2+}$ present in the olivine inclusions, as calculated in the section on 'Mantle oxidation state' above.

As the solubility of $\mathrm{Cr}^{3+}$ in the oxidised olivine is much lower than that of $\mathrm{Cr}^{2+}$ ( $\mathrm{Li}$ et al. 1995), the reaction may lead to local oversaturation of $\mathrm{Cr}$, resulting in precipitation of chromite, which would also affect the distribution of $\mathrm{Al}$ and $\mathrm{V}$, both of which are more compatible in chromite than olivine. However, no chromite micro-inclusions were observed by BSE imaging (with a maximum resolution of ca. $100 \mathrm{~nm}$ ), and sub- $\mu \mathrm{m}$ chromite inclusions are generally extremely rare in olivine inclusions in diamonds (Sobolev et al. 2008). The spatial distribution of $\mathrm{Cr}$ (Electronic Supplement, Fig. S4) shows that its distribution is highly heterogeneous on a $2-10 \mu \mathrm{m}$ scale, so if areas with excess $\mathrm{Cr}$ are the result of $\mathrm{Cr}$ being concentrated in sub- $100 \mathrm{~nm}$ inclusions of chromite, their density would need to average ca. one nanocrystal per $2 \mu \mathrm{m}^{2}$, but with a highly irregular distribution. More work is needed to fully understand the origin of $\mathrm{Cr}$ heterogeneity, and if it is present in other diamond-hosted olivine inclusion suites, particularly those where high $\mathrm{Cr}$ contents have been reported.

\section{Summary and conclusions}

- Diamond-hosted olivine inclusions from the Akwatia diamond suite were used to determine diamond paragenesis (lherzolitic vs. harzburgitic), study mantle processes such 
as melting and refertilisation, and determine physical conditions of diamond formation (pressure, temperature, oxidation state).

- Trace element compositions of olivine inclusions can be used to determine the paragenesis of host diamonds. Olivines with $\mathrm{Ca}>300 \mu \mathrm{g} / \mathrm{g}, \mathrm{Ca} / \mathrm{Al}>2.2$, and $\mathrm{Na}>60 \mu \mathrm{g} / \mathrm{g}$ or Na/Al $>0.75$ are lherzolitic (and coexist with G9 or G11 garnets), whereas olivines with $\mathrm{Ca}<100 \mu \mathrm{g} / \mathrm{g}$ or $\mathrm{Ca} / \mathrm{Al}<2.2, \mathrm{Na} \leq 60 \mu \mathrm{g} / \mathrm{g}$ and $\mathrm{Na} /$ $\mathrm{Al} \leq 0.75$ are harzburgitic (and co-exist with G10 garnets).

- To use olivine as a diamond indicator mineral, additional screening is required, as some lherzolitic low- $T$ mantle xenoliths may have olivine that fall into the harzburgitic diamond inclusion field. We recommend that the dataset is first filtered to olivines of mantle origin ( $\mathrm{Fo}=92-95 \%$ and $\mathrm{NiO}>0.3$ wt $\%$ ) with $\mathrm{Al}>40 \mu \mathrm{g} / \mathrm{g}, \mathrm{Ca}<300 \mu \mathrm{g} / \mathrm{g}$ and $\mathrm{Na}<60 \mu \mathrm{g} / \mathrm{g}$. Then 'G10' olivines are those from the filtered dataset that have at least two of the following three ratios: $\mathrm{Ca} / \mathrm{Al}<2.2, \mathrm{Al} / \mathrm{Na}>1.5$ and $\mathrm{Ca} / \mathrm{Na}<5$. If $\mathrm{Na}$ has not been measured, the filtering can be simplified to $\mathrm{Al}>40 \mu \mathrm{g} / \mathrm{g}, \mathrm{Ca}<300 \mu \mathrm{g} / \mathrm{g}$ and $\mathrm{Ca} / \mathrm{Al}<2.2$. This results in less olivines identified positively as ' $\mathrm{G} 10$ ' olivines.

- Trace-element thermometry for harzburgitic olivine is hampered by variation in the concentration of elements which are assumed to be constant in co-existing minerals, which affects $\mathrm{Ca}$ in particular. Aluminium appears to be little affected, so $T_{\mathrm{Al}-\mathrm{ol}}$ estimates are equally reliable for harzburgitic as lherzolitic olivine. Ca-ol thermometry can only be applied to lherzolitic olivines, but even those often give anomalously high temperature estimates. Trace element thermometers $\left(T_{\mathrm{Ni}-\text { grt }}, T_{\mathrm{Al}-\mathrm{ol}}\right)$ result in similar average temperatures as major element exchange thermometry but good linear correlations are not observed, indicating the possibility of disequilibrium between different silicate inclusions in the same diamond.

- Based on traditional geothermobarometry, the diamonds of the Akwatia field were derived from a continuous mantle section from the diamond-graphite boundary (ca. 140-km depth) down to ca. $200 \mathrm{~km}$ along a $38-39 \mathrm{~mW} / \mathrm{m}^{2}$ conductive geotherm. Similar results can be obtained from Al-ol thermometry, with $T_{\mathrm{Al}-\mathrm{ol}}$ ranging from $1020^{\circ} \mathrm{C}$ at $45 \mathrm{kbar}$ to $1325^{\circ} \mathrm{C}$ at $65 \mathrm{kbar}$, using the assumption that the olivine suite is derived from within the diamond stability field at temperatures below the mantle adiabat.

- Titanium in olivine correlates well with Ti in garnet, and is highest in lherzolitic olivine, whilst being extremely depleted $(<1 \mu \mathrm{g} / \mathrm{g})$ in many harzburgitic olivines, which indicates strong melt depletion with no cpx left in the residue. Lherzolitic olivines have similar Cr\# as harzburgitic olivines, so their high Ti contents are indicative of melt refertilisation during an ancient metasomatic event that occurred before trapping of the inclusions in the diamond.

- A proportion of $\mathrm{Cr}$ in olivine is present as divalent $\mathrm{Cr}$, due to the low oxidation state and high temperature of the mantle source. However, in harzburgitic olivine $\mathrm{Cr}$ and $\mathrm{V}$ are commonly lower than expected based on the equilibration temperatures. This is due to the absence of cpx in harzburgitic lithologies and the resulting low $\mathrm{Na}$ activity, which reduces the uptake of $\mathrm{Cr}$ and $\mathrm{V}$ via the $\mathrm{Na}-\mathrm{M}^{3+}$ exchange mechanism, which dominates in lherzolites.

- Chromium, $\mathrm{Al}$ and $\mathrm{V}$ distribution in many olivines is highly heterogeneous and it is recommended that multiple points are analysed on each diamond-hosted olivine inclusion to check for heterogeneity and to achieve a reliable average composition. Although the origin of the heterogeneity is unclear, the most likely cause is a latestage process, possibly hydrogen loss during diamond exhumation, resulting in oxidation of $\mathrm{Cr}^{2+}$ to $\mathrm{Cr}^{3+}$ and oversaturation of chromite.

- Olivine inclusions in diamonds can provide similar information about equilibration temperature, diamond paragenesis and mantle processes as is commonly derived from diamond-hosted garnet inclusions. To fully utilise the potential of olivine in mantle studies, it is recommended that at least the following suite of trace elements is analysed: $\mathrm{Na}, \mathrm{Al}, \mathrm{Ca}, \mathrm{Sc}, \mathrm{Ti}, \mathrm{V}, \mathrm{Cr}, \mathrm{Mn}, \mathrm{Ni}$.

Acknowledgements We thank Richard Hinton for assistance with $\mathrm{Ni}$ in garnet analysis, Ben Harte for supplying $\mathrm{Ni}$ in garnet standards and Chris Hayward for assistance with electron microprobe analysis. Constructive reviews by Peter Tollan and an anonymous reviewer are greatly appreciated.

Open Access This article is distributed under the terms of the Creative Commons Attribution 4.0 International License (http://creativeco mmons.org/licenses/by/4.0/), which permits unrestricted use, distribution, and reproduction in any medium, provided you give appropriate credit to the original author(s) and the source, provide a link to the Creative Commons license, and indicate if changes were made.

\section{References}

Ballhaus C, Berry RF, Green DH (1991) High-pressure experimental calibration of the olivine-ortho-pyroxene-spinel oxygen geobarometer-implications for the oxidation-state of the upper mantle. Contrib Mineral Petrol 107(1):27-40. https://doi.org/10.1007/ BF00311183

Ballhaus C, Berry RF, Green DH (1994) High-pressure experimental calibration of the olivine-ortho-pyroxene-spinel oxygen geobarometer-implications for the oxidation-state of the upper-mantle. Contrib Mineral Petrol 118(1):109. https://doi.org/10.1007/BF003 10615

Batanova VG, Sobolev AV, Kuzmin DV (2015) Trace element analysis of olivine: high precision analytical method for JEOL JXA-8230 
electron probe microanalyser. Chem Geol 419:149-157. https:// doi.org/10.1016/j.chemgeo.2015.10.042

Berry AJ, Shelley JMG, Foran GJ, O'Neill HS, Scott DR (2003) A furnace design for XANES spectroscopy of silicate melts under controlled oxygen fugacities and temperatures to 1773 K. J Synchrotron Radiat 10:332-336

Berry AJ, Hermann J, O’Neill HSC, Foran GJ (2005) Fingerprinting the water site in mantle olivine. Geology 33(11):869-872. https ://doi.org/10.1130/g21759.1

Berry AJ, O'Neill HSC, Hermann J, Scott DR (2007) The infrared signature of water associated with trivalent cations in olivine. Earth Planet Sci Lett 261(1-2):134-142. https://doi.org/10.1016/j. eps1.2007.06.021

Bizimis M, Salters VJM, Bonatti E (2000) Trace and REE content of clinopyroxenes from supra-subduction zone peridotites: Implications for melting and enrichment processes in island arcs. Chem Geol 165(1-2):67-85

Brey GP, Köhler T (1990) Geothermobarometry in 4-phase lherzolites. 2. New thermobarometers, and practical assessment of existing thermobarometers. J Petrol 31(6):1353-1378

Brey GP, Shu Q (2018) The birth, growth and ageing of the Kaapvaal subcratonic mantle. Mineral Petrol 112:23-41. https://doi. org/10.1007/s00710-018-0577-8

Bulanova GP (1995) The formation of diamond. J Geochem Explor 53(1-3):1-23. https://doi.org/10.1016/0375-6742(94)00016-5

Bussweiler Y, Brey GP, Pearson DG, Stachel T, Stern RA, Hardman MF, Kjarsgaard BA, Jackson SE (2017) The aluminum-in-olivine thermometer for mantle peridotites - experimental versus empirical calibration and potential applications. Lithos 272:301-314. https://doi.org/10.1016/j.lithos.2016.12.015

Canales DG, Norman DI (2003) The Akwatia diamond field, Ghana, West Africa: source rocks. In: Geological Society of America Annual Meeting, Seattle, vol 35, p 230

Canil D (1996) An experimental calibration of the "nickel in garnet", geothermometer with applications_-reply. Contrib Mineral Petrol 124(2):219-223

Canil D (1999a) The Ni-in-garnet geothermometer: calibration at natural abundances. Contrib Mineral Petrol 136(3):240-246

Canil D (1999b) Vanadium partitioning between orthopyroxene, spinel and silicate melt and the redox states of mantle source regions for primary magmas. Geochim Cosmochim Acta 63(3-4):557-572. https://doi.org/10.1016/S0016-7037(98)00287-7

Canil D (2002) Vanadium in peridotites, mantle redox and tectonic environments: archean to present. Earth Planet Sci Lett 195(12):75-90. https://doi.org/10.1016/s0012-821x(01)00582-9

Canil D, Oneill HS, Pearson DG, Rudnick RL, Mcdonough WF, Carswell DA (1994) Ferric iron in peridotites and mantle oxidation-states. Earth Planet Sci Lett 123(1-4):205-220. https://doi. org/10.1016/0012-821x(94)90268-2

Chirico PG, Malpeli KC, Anum S, Phillips EC (2010) Alluvial diamond resource potential and production capacity assessment of Ghana. USGS Scientific Investigations Report 2010-5045, p 25

Dawson JB, Stephens WE (1975) Statistical classification of garnets from kimberlite and associated xenoliths. J Geol 83(5):589-607. https://doi.org/10.2307/30061056

De Hoog JCM, Gall L, Cornell DH (2010) Trace-element geochemistry of mantle olivine and application to mantle petrogenesis and geothermobarometry. Chem Geol 270(1-4):196-215. https://doi. org/10.1016/j.chemgeo.2009.11.017

Demouchy S, Bolfan-Casanova N (2016) Distribution and transport of hydrogen in the lithospheric mantle: a review. Lithos 240:402425. https://doi.org/10.1016/j.lithos.2015.11.012

Dick HJB, Bullen T (1984) Chromian spinel as a petrogenetic indicator in abyssal and alpine-type peridotites and spatially associated Lavas. Contrib Mineral Petrol 86(1):54-76
Foley SF, Andronikov AV, Jacob DE, Melzer S (2006) Evidence from Antarctic mantle peridotite xenoliths for changes in mineralogy, geochemistry and geothermal gradients beneath a developing rift. Geochim Cosmochim Acta 70(12):3096-3120. https://doi. org/10.1016/j.gca.2006.03.010

Foley SF, Prelevic D, Rehfeldt T, Jacob DE (2013) Minor and trace elements in olivines as probes into early igneous and mantle melting processes. Earth Planet Sci Lett 363:181-191. https:// doi.org/10.1016/j.epsl.2012.11.025

Glaser SM, Foley SF, Gunther D (1999) Trace element compositions of minerals in garnet and spinel peridotite xenoliths from the Vitim volcanic field, Transbaikalia, eastern Siberia. Lithos 48(1-4):263285. https://doi.org/10.1016/S0024-4937(99)00032-8

Griffin WL, Ryan CG (1996) An experimental calibration of the " "nickel in garnet', geothermometer with applications-discussion. Contrib Mineral Petrol 124(2):216-218

Griffin WL, Cousens DR, Ryan CG, Sie SH, Suter GF (1989) Ni in chrome pyrope garnets - a new geothermometer. Contrib Mineral Petrol 103(2):199-202. https://doi.org/10.1007/Bf00378505

Grütter HS, Gurney JJ, Menzies AH, Winter F (2004) An updated classification scheme for mantle-derived garnet, for use by diamond explorers. Lithos 77(1-4):841-857. https://doi. org/10.1016/j.lithos.2004.04.012

Grütter H, Latti D, Menzies A (2006) Cr-saturation arrays in concentrate garnet compositions from kimberlite and their use in mantle barometry. J Petrol 47(4):801-820. https://doi.org/10.1093/ petrology.egi096

Gurney JJ (1984) A correlation between garnets and diamonds in kimberlites. In: Glover JE, Harris PG (eds) Kimberlite occurrence and origin: a basis for conceptual models in exploration, vol 8. Publs Geology Department and University Extension, University of Western Australia, Perth, pp 143-166

Gurney JJ, Helmstaedt H, Moore RO (1993) A review of the use and application of mantle mineral geochemistry in diamond exploration. Pure Appl Chem 65(12):2423-2442. https://doi. org/10.1351/pac199365122423

Gurney JJ, Helmstaedt HH, Richardson SH, Shirey SB (2010) Diamonds through Time. Econ Geol 105(3):689-712. https://doi. org/10.2113/gsecongeo.105.3.689

Harley SL (1984) An experimental study of the partitioning of $\mathrm{Fe}$ and $\mathrm{Mg}$ between garnet and orthopyroxene. Contrib Mineral Petrol 86(4):359-373. https://doi.org/10.1007/bf01187140

Hasterok D, Chapman DS (2011) Heat production and geotherms for the continental lithosphere. Earth Planet Sci Lett 307(1-2):5970. https://doi.org/10.1016/j.eps1.2011.04.034

Hellebrand E, Snow JE, Dick HJB, Hofmann AW (2001) Coupled major and trace elements as indicators of the extent of melting in mid-ocean-ridge peridotites. Nature 410:677-681

Hermann J, O'Neill HSC, Berry AJ (2005) Titanium solubility in olivine in the system $\mathrm{TiO}_{2}-\mathrm{MgO}-\mathrm{SiO}_{2}$ : no evidence for an ultra-deep origin of Ti-bearing olivine. Contrib Mineral Petrol 148(6):746-760. https://doi.org/10.1007/s00410-004-0637-4

Hervig RL, Smith JV (1982) Temperature-dependent distribution of $\mathrm{Cr}$ between olivine and pyroxenes in lherzolite xenoliths. Contrib Mineral Petrol 81(3):184-189

Hervig RL, Smith JV, Steele IM (1980a) Fertile and barren Al-Crspinel harzburgites from the upper mantle-ion and electronprobe analyses of trace-elements in olivine and ortho-pyroxene-relation to lherzolites. Earth Planet Sci Lett 50(1):41-58

Hervig RL, Smith JV, Steele IM, Gurney JJ, Meyer HOA, Harris JW (1980b) Diamonds-minor elements in silicate inclusions-pressure-temperature implications. J Geophys Res 85(B12):6919-6929

Hervig RL, Smith JV, Dawson JB (1986) Lherzolite xenoliths in kimberlites and basalts: petrogenetic and crystallochemical 
significance of some minor and trace elements in olivine, pyroxenes, garnet and spinel. Trans R Soc Edinb Earth Scis $77: 181-201$

Ingrin J, Skogby H (2000) Hydrogen in nominally anhydrous upper-mantle minerals: concentration levels and implications. Eur J Miner 12(3):543-570. https://doi. org/10.1127/0935-1221/2000/0012-0543

Ionov DA (2010) Petrology of mantle wedge lithosphere: new data on supra-subduction zone peridotite xenoliths from the Andesitic Avacha Volcano, Kamchatka. J Petrol 51(1-2):327-361. https ://doi.org/10.1093/petrology/egp090

Irving AJ, Frey FA (1978) Distribution of trace elements between garnet megacrysts and host volcanic liquids of kimberlitic to rhyolitic composition. Geochim Cosmochim Acta 42(6):771-787

Ivanic TJ (2007) The chromite-garnet peridotite assemblages and their role in the evolution of the mantle lithosphere. Unpublished Ph.D. thesis. University of Edinburgh, Edinburgh

Jarosewich E, Nelen J, Norber J (1980) Reference samples for electron probe analysis. Geostand Newslett 4(1):43-47

Jochum KP, Willbold M, Raczek I, Stoll B, Herwig K (2005) Chemical characterisation of the USGS reference glasses GSA-1G, GSC$1 \mathrm{G}$, GSD-1G, GSE-1G, BCR-2G, BHVO-2G and BIR-1G using EPMA, ID-TIMS, ID-ICP-MS and LA-ICP-MS. Geostand Geoanal Res 29(3):285-302

Kennedy CS, Kennedy GC (1976) The equilibrium boundary between graphite and diamond. J Geophys Res 81(14):2467-2470

Klemme S (2004) The influence of $\mathrm{Cr}$ on the garnet-spinel transition in the Earth's mantle: experiments in the system $\mathrm{MgO}-\mathrm{Cr} 2 \mathrm{O} 3-\mathrm{SiO} 2$ and thermodynamic modelling. Lithos 77(1-4):639-646. https:// doi.org/10.1016/j.lithos.2004.03.017

Klemme S, Ivanic TJ, Connolly JAD, Harte B (2009) Thermodynamic modelling of Cr-bearing garnets with implications for diamond inclusions and peridotite xenoliths. Lithos 112:986-991

Köhler T, Brey GP (1988) Ca in olivine as a geobarometer for lherzolites. Chem Geol 70(1-2):10

Köhler TP, Brey GP (1990) Calcium exchange between olivine and clinopyroxene calibrated as a geothermobarometer for natural peridotites from 2 to $60 \mathrm{~kb}$ with applications. Geochim Cosmochim Acta 54(9):2375-2388

Krogh EJ (1988) The garnet-clinopyroxene Fe-Mg geothermometer-a reinterpretation of existing experimental-data. Contrib Mineral Petrol 99(1):44-48

Kurosawa M, Yurimoto H, Sueno S (1997) Patterns in the hydrogen and trace element compositions of mantle olivines. Phys Chem Miner 24(6):385-395

Li JP, O'Neill HSC, Seifert F (1995) Subsolidus phase-relations in the system $\mathrm{MgO}-\mathrm{SiO} 2-\mathrm{Cr}-\mathrm{O}$ in equilibrium with metallic $\mathrm{Cr}$, and their significance for the petrochemistry of chromium. J Petrol 36(1):107-132

Luth RW, Stachel T (2014) The buffering capacity of lithospheric mantle: implications for diamond formation. Contrib Miner Petrol 168:1083. https://doi.org/10.1007/s00410-014-1083-6

Mallmann G, O'Neill HSC (2009) The crystal/melt partitioning of V during mantle melting as a function of oxygen fugacity compared with some other elements (Al, P, Ca, Sc, Ti, Cr, Fe, Ga, Y, Zr and Nb). J Petrol 50(9):1765-1794. https://doi.org/10.1093/petro logy/egp053

Mallmann G, O'Neill HSC, Klemme S (2009) Heterogeneous distribution of phosphorus in olivine from otherwise well-equilibrated spinel peridotite xenoliths and its implications for the mantle geochemistry of lithium. Contrib Miner Petrol 158(4):485-504. https ://doi.org/10.1007/s00410-009-0393-6

Matsyuk SS, Langer K (2004) Hydroxyl in olivines from mantle xenoliths in kimberlites of the Siberian platform. Contrib Miner Petrol 147(4):413-437. https://doi.org/10.1007/s00410-003-0541-3
Matveev S, Stachel T (2007) FTIR spectroscopy of OH in olivine: a new tool in kimberlite exploration. Geochim Cosmochim Acta 71(22):5528-5543

Milman-Barris MS, Beckett JR, Baker MB, Hofmann AE, Morgan Z, Crowley MR, Vielzeuf D, Stolper E (2008) Zoning of phosphorus in igneous olivine. Contrib Miner Petrol 155(6):739-765

Nimis P, Taylor WR (2000) Single clinopyroxene thermobarometry for garnet peridotites: Part I. Calibration and testing of a Cr-in-Cpx barometer and an enstatite-in-Cpx thermometer. Contrib Miner Petrol 139(5):541-554

O’Neill HSC, Wood BJ (1979) Experimental study of Fe-Mg partitioning between garnet and olivine and iIts calibration as a geothermometer. Contrib Miner Petrol 70(1):59-70

Papike JJ, Karner JM, Shearer CK (2005) Comparative planetary mineralogy: valence state partitioning of $\mathrm{Cr}, \mathrm{Fe}, \mathrm{Ti}$, and $\mathrm{V}$ among crystallographic sites in olivine, pyroxene, and spinel from planetary basalts. Am Miner 90(2-3):277-290. https://doi.org/10.2138/ am.2005.1779

Phillips D, Harris JW, Viljoen KS (2004) Mineral chemistry and thermobarometry of inclusions from De Beers Pool diamonds, Kimberley, South Africa. Lithos 77(1-4):155-179. https://doi. org/10.1016/j.lithos.2004.04.005

Pirard C, Hermann J, O’Neill HS (2013) Petrology and Geochemistry of the crust-mantle boundary in a Nascent Arc, Massif du Sud Ophiolite, New Caledonia, SW Pacific. J Petrol 54(9):1759-1792. https://doi.org/10.1093/petrology/egt030

Rehfeldt T, Foley SF, Jacob DE, Carlson RW, Lowry D (2008) Contrasting types of metasomatism in dunite, wehrlite and websterite xenoliths from Kimberley, South Africa. Geochim Cosmochim Acta 72(23):5722-5756. https://doi.org/10.1016/j. gca.2008.08.020

Rudnick RL, Nyblade AN (1999) The thickness and heat production of Archean lithosphere: constraints from xenolith thermobarometry and surface heat flow. In: Fei Y, Bertka CM, Mysen BO (eds) Mantle petrology: Field observations and high pressure experimentation; a tribute to Francis R (Joe) Boyd. Special Publication No. 6, The Geochemical Society, Washington, pp 3-12

Russell JK, Porritt LA, Lavallee Y, Dingwell DB (2012) Kimberlite ascent by assimilation-fuelled buoyancy. Nature 481:352-356. https://doi.org/10.1038/nature10740

Ryan CG, Griffin WL, Pearson NJ (1996) Garnet geotherms: pressuretemperature data from Cr-pyrope garnet xenocrysts in volcanic rocks. J Geophys Res Solid Earth 101(B3):5611-5625

Schreiber HD, Merkel RC, Schreiber VL, Balazs GB (1987) Mutual interactions of redox couples via electron exchange in silicate melts-models for geochemical melt systems. J Geophys ResSolid 92(B9):9233-9245. https://doi.org/10.1029/Jb092ib09p 09233

Shchukina EV, Shchukin VS (2018) Diamond exploration potential of the Northern East European Platform. Minerals 8(5):189. https:// doi.org/10.3390/min8050189

Smith EM, Shirey SB, Richardson SH, Nestola F, Bullocks ES, Wang JH, Wang WY (2018) Blue boron-bearing diamonds from Earth's lower mantle. Nature 560:84-87. https://doi.org/10.1038/s4158 6-018-0334-5

Sobolev NV, Lavrente YG, Pokhilenko NP, Usova LV (1973) Chromerich garnets from kimberlites of Yakutia and their parageneses. Contrib Miner Petrol 40(1):39-52. https://doi.org/10.1007/bf003 71762

Sobolev NV, Logvinova AM, Zedgenizov DA, Pokhilenko NP, Kuzmin DV, Sobolev AV (2008) Olivine inclusions in Siberian diamonds: high-precision approach to minor elements. Eur J Miner 20(3):305-315. https://doi. org/10.1127/0935-1221/2008/0020-1829

Sobolev NV, Logvinova AM, Zedgenizov DA, Pokhilenko NP, Malygina EV, Kuzmin DV, Sobolev AV (2009) Petrogenetic 
significance of minor elements in olivines from diamonds and peridotite xenoliths from kimberlites of Yakutia. Lithos 112:701713. https://doi.org/10.1016/j.lithos.2009.06.038

Stachel T, Harris JW (1997a) Diamond precipitation and mantle metasomatism - evidence from the trace element chemistry of silicate inclusions in diamonds from Akwatia, Ghana. Contrib Miner Petrol 129(2-3):143-154

Stachel T, Harris JW (1997b) Syngenetic inclusions in diamond from the Birim field (Ghana) - a deep peridotitic profile with a history of depletion and re-enrichment. Contrib Miner Petrol 127(4):336-352

Stachel T, Harris JW (2008) The origin of cratonic diamonds-constraints from mineral inclusions. Ore Geol Rev 34(1-2):5-32

Stachel T, Viljoen KS, Brey G, Harris JW (1998) Metasomatic processes in lherzolitic and harzburgitic domains of diamondiferous lithospheric mantle: REE in garnets from xenoliths and inclusions in diamonds. Earth Planet Sci Lett 159(1-2):1-12. https://doi. org/10.1016/S0012-821X(98)00064-8

Stagno V, Ojwang DO, McCammon CA, Frost DJ (2013) The oxidation state of the mantle and the extraction of carbon from Earth's interior. Nature 493:84-88. https://doi.org/10.1038/nature11679

Stead CV, Tomlinson EL, Kamber BS, Babechuk MG, McKenna CA (2017) Rare earth element determination in olivine by laser ablation-quadrupole-ICP-MS: an analytical strategy and applications. Geostand Geoanal Res 41(2):197-212. https://doi.org/10.1111/ ggr. 12157

Steele IM, Hervig RL, Hutcheon ID, Smith JV (1981) Ion microprobe techniques and analyses of olivine and low-Ca pyroxene. Am Miner 66:526-546
Stosch HG (1981) Sc, Cr, Co and Ni partitioning between minerals from spinel peridotite xenoliths. Contrib Miner Petrol 78(2):166-174

Sutton SR, Bajt AS, Rivers ML, Smith JV (1993) X-ray microprobe determination of chromium oxidation state in olivine from lunar basalt and kimberlitic diamonds. In: $24^{\text {th }}$ Lunar and Planetary Science Conference. Houston, TX, pp 1383-1384

Tollan PME, Dale CW, Hermann J, Davidson JP, Arculus RJ (2017) Generation and modification of the mantle wedge and lithosphere beneath the west bismarck island arc: melting, metasomatism and thermal history of peridotite xenoliths from Ritter Island. J Petrol 58(8):1475-1510. https://doi.org/10.1093/petrology/egx062

Tollan PME, O'Neill HS, Hermann J (2018) The role of trace elements in controlling H incorporation in San Carlos olivine. Contrib Miner Petrol 173(11):ARTN89

Witt-Eickschen G, O'Neill HS (2005) The effect of temperature on the equilibrium distribution of trace elements between clinopyroxene, orthopyroxene, olivine and spinel in upper mantle peridotite. Chem Geol 221(1-2):65-101. https://doi.org/10.1016/j. chemgeo.2005.04.005

Wu CM, Zhao GC (2007) A recalibration of the garnet-olivine geothermometer and a new geobarometer for garnet peridotites and garnet-olivine-plagioclase-bearing granulites. J Metamorph Geol 25(5):497-505

Publisher's Note Springer Nature remains neutral with regard to jurisdictional claims in published maps and institutional affiliations. 